Sociālo zinātṇu fakultāte

SEKCIJA "DEZINFORMĀCIJAS UN SAZVËRESTİBU RADITTIE RISKI DEMOKRĀTIJAI:

LATVIJAS PIEREDZES PĀRLÜKOŠANA"

Kopsavilkumi

\section{9.} \\ .8}

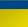

Latvijas Universitātes starptautiskā zinātniskā konference 
79. Latvijas Universitātes starptautiskā zinātniskā konference

79 ${ }^{\text {th }}$ International Scientific Conference of the University of Latvia

Sociālo zinātṇu fakultāte

\section{SEKCIJA "DEZINFORMĀCIJAS UN SAZVĒRESTĪBU RADĪTIE RISKI DEMOKRĀTIJAI: LATVIJAS PIEREDZES PĀRLŪKOŠANA"}

Kopsavilkumi

Faculty of Social Sciences

SESSION "JEOPARDIZING DEMOCRACY THROUGH DISINFORMATION AND CONSPIRACIES: RECONSIDERING EXPERIENCE OF LATVIA"

Abstracts

2021. gada 25. un 26. februāris February 25 and 26, 2021 
Zelče, V. (red.). Latvijas Universitātes 79. starptautiskā zinātniskā konference. Sociālo zinātñu fakultāte. Sekcija "Dezinformācijas un sazvērestību radītie riski demokrātijai: Latvijas pieredzes pārlūkošana". Kopsavilkumi. Rīga: Latvijas Universitāte, 2021. 57 lpp.

Zelče, V. (ed.). $79^{\text {th }}$ International Scientific Conference of the University of Latvia. Faculty of Social Sciences. Session "Jeopardizing Democracy through Disinformation and Conspiracies: Reconsidering Experience of Latvia" Abstracts. Riga: University of Latvia, 2021. 57 p.
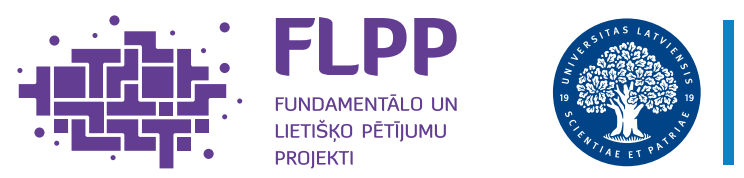
FAKULTĀTE

Sekcijā izskanējušajos ziṇojumos atspoguḷoti Latvijas Zinātnes padomes fundamentālo un lietišķo projektu programmas projekta "Dezinformācijas un sazvērestību radītie riski demokrātijai: Latvijas pieredzes pārlūkošana” (lzp-2019/1-0278) rezultāti. Krājums izdots ar Latvijas Zinātnes padomes atbalstu.

The reports presented in the session contain the results of the project "Risks to Democracy Caused by Disinformation and Conspiracy: Reviewing the Latvian Experience" (lzp-2019/1-0278) of Fundamental and Applied Project Programme by Latvian Council of Science. Published with support from Latvian Council of Science.

Sastādītāja un zinātniskā redaktore Vita Zelče / Edited by Vita Zelče Literārais redaktors Oskars Lapsiņš / Literary editor Oskars Lapsiņš Angḷu valodas redaktors Oskars Gruziņš / English language editor Oskars Gruziņš Maketētāja Žanna Kresso / Layout Žanna Kresso

(C) Abstraktu autori/Authors of abstracts, 2021

(C) Latvijas Universitāte/University of Latvia, 2021

ISBN 978-9934-18-752-0 (PDF)

https://doi.org/10.22364/luszk.79.szf.01 


\section{SATURS / CONTENT}

\section{Vita Zelče}

Dezinformācijas un sazvērestību pētījumu teorētiskās pieejas

Vita Zelče

Theoretical Approaches to Disinformation and Conspiracy Research

\section{Lelde Neimane}

Informācija un dezinformācija deportāciju laikā. 1941. gada 14. jūnija

deportācijas piemērs

\section{Lelde Neimane}

Information and Disinformation During Soviet Mass Deportations.

Example of the Deportation of June $14^{\text {th }} 1941$

\section{Evita Feldentāle}

Informācija un dezinformācija deportāciju laikā. 1949. gada 25. marta

deportācijas piemērs

\section{Evita Feldentāle}

Information and Disinformation. Example of the Mass Deportation of March $25^{\text {th }}, 1949$

\section{Oskars Gruziṇš}

Padomju un nacistu represijās izdzīvojušo gimenes atmiņa: refleksijas par "kara dzemdināto bērnu" mutvārdu vēstures liecībām

\section{Oskars Gruziņš}

Family Memories of Survival in the Period of Soviet and Nazi Repression:

Reflections on the Oral History Testimonies of Latvian "Children

Born of War"

\section{Viesturs Zanders}

Preses izdevumi kā dezinformācijas instruments Latvijā un trimdā

(20. gadsimta 50.-60. gadi)

\section{Viesturs Zanders}

Press Publications as a Means of Disinformation in Latvia and in Latvian

Exile Communities (the 1950s and 1960s)

\section{Skaidrīte Lasmane}

Melu daudzveidỉba un ētika

\section{Skaidrīte Lasmane}

The Diversity and Ethics of Lies

\section{Ojārs Skudra}

Demokrātijas krīzes un Latvijas relatīvās atpalicības rāmējumi akadēmiskajās un mediju publikācijās: sistēmtransformācijas, sabiedrības mediatizācijas un publiskā viedokḷa aspekti (2018-2021) 


\section{Ojārs Skudra}

Frames of Democratic Crisis and the Relative Backwardness of Latvia in Academic and Media Publications: The Aspects of Systemic Transformations,

Mediatization of Society and Public Opinion (2018-2021)

Ilze Matīse-VanHoutana, Lilija Geine-Romanova

Suṇu barības ražotāja publiskā retorika ar barību saistītajā megaesophagus

uzliesmojumā suṇiem: Latvijas gadījums (2015-2016)

Ilze Matīse-Van Houtana, Lilija Geine-Romanova

Public Rhetoric of a Dog Food Manufacturer in a Food-Related Megaesophagus

Outbreak in Dogs: Outbreak in Latvia (2015-2016)

Ilze Matīse-VanHoutana, Lilija Geine-Romanova

Suṇu barības ražotāja publiskā retorika ar barību saistītajā megaesophagus

uzliesmojumā suṇiem: Austrālijas gadījums (2017-2018)

Ilze Matīse-Van Houtana, Lilija Geine-Romanova

Public Rhetoric of a Dog Food Manufacturer in a Food-Related Outbreak of Megaesophagus in Dogs: Outbreak in Australia (2017-2018) 46

\section{Mārtiņš Pričins}

Sazvērestības teoriju lokalizācijas piemēri sociālās tīklošanās vietnē Facebook

\section{Mārtiņš Pričins}

Examples of Localization of Conspiracy Theories on the Social Networking

Site Facebook

\section{Marita Zitmane}

Dzimumu līdztiesība 2020. gadā Covid-19 pandēmijas ietekmē

Marita Zitmane

The Impact of the Covid-19 Pandemic on Gender Equality in 2020 


\title{
DEZINFORMĀCIJAS UN SAZVĒRESTĪBU PĒTİJUMU TEORĒTISKĀS PIEEJAS
}

\author{
Vita Zelče \\ $\bigotimes$ vita.zelce@lu.lv \\ ORCID: https://orcid.org/0000-0002-5169-8862
}

Latvijas Zinātnes padomes fundamentālo un lietišķo pētījumu programmas projekta "Dezinformācijas un sazvērestību radītie riski demokrātijai: Latvijas pieredzes pārlūkošana" mērḳis ir starpdisciplinārā griezumā pētīt dezinformācijas un sazvērestību vēstījumu vietu Latvijas informācijas telpā, kā arī tās ietekmi uz cilvēku dzīvi, veselību, drošību un labklājību, iztirzājot Latvijas sabiedrības pieredzi 20. gadsimta totalitārisma laikmetā un periodā pēc neatkarības atgūšanas, un izvērtēt dezinformācijas un sazvērestību radītos riskus mūsdienu demokrātijai un tās vērtībām. Projekts tiek īstenots divos virzienos: 1) vēstures pētījumi veltīti dezinformācijas plūsmu un sazvērestību dinamikai kopš 20. gadsimta 30. gadu vidus, kad Latvija pārstāja būt demokrātiska valsts un piedzīvoja divu totalitāru režīmu okupāciju; 2) mūsdienu pētījumi, kuros tiek analizēta dezinformācijas un sazvērestību esamība Latvijas informativvajā telpā, it īpaši digitālajos medijos. Projekta īstenošana tika sākta pirms Covid-19 radītās krīzes un tās iniciēto dezinformācijas un sazvērestību teoriju uzplaukuma. Neapšaubāmi, šīs norises ir ietekmējušas pētījuma mērķus un tematiku, likušas modificēt pētījuma jautājumus. Vērojams, ka pēdējā desmitgadē akadēmiskās literatūras klāsts par dezinformāciju un strauji aug un proliferē. Ar terminu "dezinformācija" tiek apzīmēta nepatiesa, neprecīza un/vai maldinoša informācija, kas radīta, pasniegta, izplatīta un popularizēta, lai tīši nodarìtu kaitējumu sabiedrībai un/vai gūtu pel̦nu (EC 2018). Tā var ietvert nepatiesas ziņas un mākslīgi radītus dokumentālos formātus, kā arī vēl rafinētākas dezinformēšanas metodes, piemēram, neīstu karogu un simbolu lietošanu, neprecīzus un/vai viltotus ietekmīgu personu citējumus, izdomātus notikumus un sagudrotus stāstus, kurus tālāk nodod "uzticami l̦audis". Šie līdzekḷi apzināti veicina dezinformācijas izplatību, jau stratēgésiski nodrošina sistemātiskākus autoritatīvas informācijas plūsmas traucējumus un maldina sabiedrību, kas to patērē, būdama pārliecināta par šīs informācijas ticamību (Bennett, Livingston 2018; Tandor et al. 2019). Cīṇa ar dezinformāciju ir viens no prioritārajiem Eiropas Savienības institūciju uzdevumiem. Eiropadome tiešsaistē īstenotās dezinformācijas kampaņas atzina kā apdraudējumu 2015. gadā, izvērtējot Krievijas Federācijas dezinformācijas kampaņu ietekmi uz sabiedrību. 2018. gada decembrī Eiropas Komisija pieñēma "Rīcībplānu pret dezinformāciju", kura uzdevums - bez kavēšanās sākt darbības, lai pasargātu Eiropas Savienības (ES) iedzīvotājus pret dezinformāciju. Arī viens no Latvijas mediju politikas galvenajiem uzdevumiem ir medijpratības veicināšana, tādējādi radot priekšnoteikumus dezinformācijas ietekmes mazināšanai (Kultūras ministrija 2016).

Dezinformācijas plūsmu izpratnē svarīga nozīme ir arī sazvērestības teorētiskajām pieejām. Akadēmiskajā apritē tās kā sociāli nozīmīgas problēmas iztirzājums 
nonāca 20. gadsimta 50.-60. gados, kad to aktualizēja filozofs Karls Popers (Popper [1952] 2011). Sazvērestības teorijas un ticība tām ir bijusi izplatīta visā cilvēces vēstures gaitā, to rašanās un uzplaukuma periodi allaž saistāmi ar sociālās krīzes situācijām. To laikā sabiedrībā norisinās kardinālas pārmaiṇas, kas daudziem sagrauj līdz tam pastāvējušo priekšstatu par varas struktūrām, sociālās uzvedības normām, maina konkrētu cilvēku un sociālo grupu vērtējumu. Sazvērestības teoriju analīze sniedz zināšanas par to, kā sabiedrība konkrētā valstī, reǵiona vai pasaules daḷā veidojusi attiecības ar savu vēsturi, kāda bijusi tās sociālā un garīgā stabilitāte, kā tā pārdzīvojusi krīzes. Ticība sazvērestībām ir izteikta dezinformācijas pavadošā parādība (piemēram, Heins 2007; Sustein, Vermeule 2009; Dentith 2018; Butter, Knight 2000). Dezinformācijas un sazvērestības teoriju satura, izplatīšanas kanālu un ietekmes pētijumu uzmanības centrā izteikti ir Donalda Trampa (Donald Trump) ievēlēšana ASV prezidenta amatā 2016. gadā un breksits (Brexit) 2017. gadā (piemēram, Evans, Menon 2017; Kakutani 2018; Hellinger 2019). Protams, pašreiz ìpaši aktuāli ir pētijumi par dezinformāciju un sazvērestības teorijām Covid-19 radītajā krīzes situācijā (piemēram, Fuchs 2021; Lilleker et al. 2021). Plašs literatūras klāsts veltīts arī šo fenomenu uzplaukumiem noteiktu vēstures norišu laikā un to vēlākās interpretācijās, piemēram, nacistu antisemìtiskajai politikai un holokaustam, Džona Kenedija (John Kennedy) slepkavībai, 2001. gada 11. septembra uzbrukumam ASV (piemēram, Ezergailis 2005; Prooijen, Douglas 2017; Fay 2019). Nesenais digitālo mediju uzplaukums un dezinformācijas izplatība radījusi nopietnus izaicinājumus liberālajai demokrātijai, tostarp uzticības kritumu žurnālistikai un mediju institūcijām, manipulācijas lēmumpieņemšanas procesos, toksiskuma pieaugumu tiešsaistes komunikācijā (Culloty, Suiter 2021). Dezinformācija un sazvērestības ne tikai apdraud cilvēku veselību, drošību un labklājību, zināšanās balstītas sabiedrības esamības normatīvus, bet arī ir labvēlīgas populisma un radikālu ideoloǵiju uzplaukumam.

Atslēgvārdi: dezinformācija, sazvērestības teorijas, sociālā krīze, dezinformācijas un sazvērestību vēsture, draudi drošībai

\section{Atsauces}

Bennett, W. L., Livingston, S. (2018). The Disinformation Order: Disruptive Communication and the Decline of Democratic Institutions. European Journal of Communication, 33(2), 122-139. DOI: $10.1177 / 0267323118760317$

Butter, M., Knight, P. (eds). (2000). Routledge Handbook of Conspiracy Theories. London: Routledge.

Culloty, E., Suiter, J. (2021). Disinformation and Manipulation in Digital Media: Information Pathologies. London; New York: Routledge.

Dentith, MR. X. (2018). Expertise and Conspiracy Theories. Social Epistemology, 32(3), 196-208. DOI: $10.1080 / 02691728.2018 .1440021$

EC (2018). A Multi-Dimensional Approach to Disinformation. Report of the Independent High level GrouponFakeNewsandOnlineDisinformation. Brussels:EuropeanCommission. Retrievedfrom: https://ec.europa.eu/digital-single-market/en/news/final-report-high-level-expert-groupfake-news-and-online-disinformation

Evans, G., Menon, A. (2017). Brexit and British Politics. Cambridge: Polity Press. 
Ezergailis, A. (2005). Nazi/Soviet disinformation about the Holocaust in Nazi-Occupied Latvia: Daugavas Vanagi - who are they? Rīga: Latvijas 50 gadu okupācijas muzeja fonds.

Fay, B. (2019). The Nazi Conspiracy Theory: German Fantasies and Jewish Power in the Third Reich. Library \& Information History, 35(2), 75-97. DOI: 10.1080/17583489.2019.1632574

Fuchs, C. (2021). Communicating Covid-19. Everyday Life, Digital Capitalism, and Conspiracy Theories in Pandemic Times. Bingley: Emerald Publishing.

Heins, V. (2007). Critical Theory and the Traps of Conspiracy Thinking. Philosophy \& Social Criticism, 33(7), 787-801. DOI: 10.1177/0191453707081675

Hellinger, D. C. (2019). Conspiracies and Conspiracy Theories in the Age of Trump. New York: Palgrave Macmillan.

Kakutani, M. (2018). The Death of Truth: Notes on Falsehood in the Age of Trump. New York: Tim Duggan Books.

Kultūras ministrija (2016). Latvijas mediju politikas pamatnostādnes 2016.-2020. gadam. Izgūts no: http://www.km.gov.lv/lv/starpnozares/lidzdaliba/pazMedPol_plan_Pamatnost.html

Lilleker, D., Coman, I. A., Gregor. M., Novelli, E. (eds). (2021). Political Communication and Covid-19. Governance and Rhetoric in Times of Crisis. London; New York: Routledge.

Popper, K. R. ([1952] 2011). The Open Society and Its Enemies. $2^{\text {nd }}$ ed. London: Routledge.

Prooijen, J.-W. van, Douglas, K. M. (2017). Conspiracy Theories as Part of History: The Role of Societal Crisis Situations. Memory Studies, 10(3), 323-333. DOI: 10.1177/1750698017701615

Tandoc Jr., E. C., Lim, D., Ling, R. (2019). Diffusion of Disinformation: How Social Media Users Respond to Fake News and Why. Journalism, 1-18. DOI: 10.1177/1464884919868325

Vermeule, A., Sunstein, C. (2009). Conspiracy Theories: Causes and Cures. Journal of Political Philosophy, 17, 202-227. DOI: 10.1111/j.1467-9760.2008.00325.x 


\title{
THEORETICAL APPROACHES TO DISINFORMATION AND CONSPIRACY RESEARCH
}

\author{
Vita Zelče \\ $\bigotimes$ vita.zelce@lu.lv \\ ORCID: https://orcid.org/0000-0002-5169-8862
}

The goal of project "Jeopardizing Democracy through Disinformation and Conspiracies: Reconsidering Experience of Latvia," a programme of Fundamental and Applied Research Projects by the Latvian Council of Science, is to study the role of disinformation and conspiracy theories in Latvia's information environment from an interdisciplinary perspective as well as to look at how these influence the lives, health, security and welfare of people. The study will discuss the experience of Latvia's society during the $20^{\text {th }}$ century, the age of totalitarianism and the period after the restoration of independence. Another aim is to evaluate the risks which disinformation and conspiracy theories cause to present-day democracy and its values. There are two areas of research. First, historical research will examine the flow of disinformation and the trends of trust in conspiracies since the mid-1930s, when Latvia was no longer a democratic country and subsequently experienced occupation by two totalitarian powers. Second, the project will focus on the presence of disinformation and conspiracy theories in the present-day Latvian information environment, particularly in the digital media. It should be noted that the project was launched before the Covid-19 crisis and the flourishing of related disinformation and conspiracy theories. Undoubtedly, these developments have influenced the aims and issues of the research, leading to additional research questions. The range of academic literature on disinformation has been growing and proliferating rapidly in the last decade. The term "disinformation" conceptually means false, inaccurate or misleading information designed, presented and promoted intentionally for profit or in order to harm the public (EC 2018, 10). This can include false news and simulated documentary formats, or it can involve subtler methods such as false flag and symbol operations, feeding inaccurate quotes or stories to innocent intermediaries or knowingly amplifying biased and/or misleading information. Research of disinformation calls for a look at more systematic disruptions of authoritative information flows due to strategic deceptions that may appear very credible to those consuming them (Bennett, Livingston 2008; Tandoc et al. 2019). The battle against disinformation is a priority for the institutions of the European Union. In 2015, with the discovery of Russian campaigns of malice information, the European Council first recognised the threat of online disinformation. In December 2018, the European Commission approved an "Action Plan Against Disinformation," which calls for urgent and immediate action to protect the Union, its institutions and its citizens, against disinformation. In Latvia, too, a key issue for media policies is to facilitate media literacy, as a precondition for the lessening of the influence of disinformation (Ministry of Culture 2016). 
Also of importance are theoretical approaches to conspiracies that are applicable to the current situation. In academic circles, a discussion of this public problem, initiated by Popper ([1952]2011), appeared in the 1950s and 1960s. Conspiracy theories have been prevalent throughout human history, and the periods during which they have appeared and flourished have been linked to social crisis situations. These can be described as impactful and of rapid social change, situations that calls established power structures, norms of conduct and even the existence of specific people or groups into question. Analysis of conspiracy theories can offer an idea about how people in a specific country, region or section of the world remember and mentally represent historical events and existing lives. Trust in conspiracies is a distinct phenomenon which accompanies disinformation (e. g., Heins 2007; Sustein, Vermeule 2009; Dentith 2018; Butter, Knight 2000). The current centre of attention in such research, regarding the content of disinformation, the channels whereby it is spread and the extent to which people are influenced by it, relates to the election of Donald Trump in 2016 and the Brexit situation in 2017 (e. g., Evans, Menon 2017; Kakutani 2018; Hellinger 2019). Of course, research of these phenomena in the Covid-19 crisis is particularly relevant (e. g., Fuchs 2021; Lilleker et al. 2021). Yet this phenomenon also relates to historical events, such as the anti-Semitic policies of the Nazis and the Holocaust, the assassination of JFK and 9/11 (e. g., Ezergailis 2005; Prooijen, Douglas 2017; Fay 2019). Recent advances in digital media have created new and serious challenges against liberal democracy. Challenges that include the spread of disinformation, a declining trust of journalism and the media, increasing manipulation of decision-making processes as well as an increasing toxicity of the internet (Culloty, Suiter 2021). Disinformation and conspiracies endanger human health, security, welfare, and the existence of a knowledge-based society. Such adverse effects are favorable for the spread of populism and radical theories.

Keywords: disinformation, conspiracy theories, social crises, history of disinformation and conspiracies, security threats

\section{References}

Bennett, W. L., Livingston, S. (2018). The Disinformation Order: Disruptive Communication and the Decline of Democratic Institutions. European Journal of Communication, 33(2), 122-139. DOI: $10.1177 / 0267323118760317$

Butter, M., Knight, P. (eds). (2000). Routledge Handbook of Conspiracy Theories. London: Routledge.

Culloty, E., Suiter, J. (2021). Disinformation and Manipulation in Digital Media: Information Pathologies. London; New York: Routledge.

Dentith, MR. X. (2018). Expertise and Conspiracy Theories. Social Epistemology, 32(3), 196-208. DOI: $10.1080 / 02691728.2018 .1440021$

EC (2018). A Multi-Dimensional Approach to Disinformation. Report of the Independent High level Group on Fake News and Online Disinformation. Brussels: European Commission. Retrieved from: https://ec.europa.eu/digital-single-market/en/news/final-report-high-level-expert-groupfake-news-and-online-disinformation

Evans, G., Menon, A. (2017). Brexit and British Politics. Cambridge: Polity Press.

Ezergailis, A. (2005). Nazi/Soviet disinformation about the Holocaust in Nazi-Occupied Latvia: Daugavas Vanagi - who are they? Rīga: Latvijas 50 gadu okupācijas muzeja fonds. 
Fay, B. (2019). The Nazi Conspiracy Theory: German Fantasies and Jewish Power in the Third Reich. Library \& Information History, 35(2), 75-97. DOI: 10.1080/17583489.2019.1632574

Fuchs, C. (2021). Communicating Covid-19. Everyday Life, Digital Capitalism, and Conspiracy Theories in Pandemic Times. Bingley: Emerald Publishing.

Heins, V. (2007). Critical Theory and the Traps of Conspiracy Thinking. Philosophy \& Social Criticism, 33(7), 787-801. DOI: 10.1177/0191453707081675

Hellinger, D. C. (2019). Conspiracies and Conspiracy Theories in the Age of Trump. New York: Palgrave Macmillan.

Kakutani, M. (2018). The Death of Truth: Notes on Falsehood in the Age of Trump. New York: Tim Duggan Books.

Ministry of Culture (2016). Latvian Media Policy Guidelines, 2016-2020 [in Latvian]. Retrieved from: http://www.km.gov.lv/lv/starpnozares/lidzdaliba/pazMedPol_plan_Pamatnost.html

Lilleker, D., Coman, I. A., Gregor. M., Novelli, E. (eds). (2021). Political Communication and Covid-19. Governance and Rhetoric in Times of Crisis. London; New York: Routledge.

Popper, K. R. ([1952] 2011). The Open Society and Its Enemies. $2^{\text {nd }}$ ed. London: Routledge.

Prooijen, J.-W. van, Douglas, K. M. (2017). Conspiracy Theories as Part of History: The Role of Societal Crisis Situations. Memory Studies, 10(3), 323-333. DOI: 10.1177/1750698017701615

Tandoc Jr., E. C., Lim, D., Ling, R. (2019). Diffusion of Disinformation: How Social Media Users Respond to Fake News and Why. Journalism, 1-18. DOI: 10.1177/1464884919868325

Vermeule, A., Sunstein, C. (2009). Conspiracy Theories: Causes and Cures. Journal of Political Philosophy, 17, 202-227. DOI: 10.1111/j.1467-9760.2008.00325.x 


\title{
INFORMĀCIJA UN DEZINFORMĀCIJA \\ DEPORTĀCIJU LAIKĀ. 1941. GADA 14. JŪNIJA DEPORTĀCIJAS PIEMĒRS
}

\author{
Lelde Neimane \\ $\triangle$ lelde.neimane@omf.lv \\ ORCID: https://orcid.org/0000-0002-3960-4536
}

Mūsdienu laikmetu raksturo l̦oti plašs pieejamās informācijas apjoms, un tikai pašu cilvēku inteliǵences, zināšanu un sapratnes bāze l̦auj tajā plūsmā neapmaldīties. Iezīmējas virziens - ar šodienas terminu un aktualitāšu starpniecību labāk izprast vēstures norises, un otrādi - no vēstures gūtās atziṇas lietot šodienas dzīvē. Informācijas un dezinformācijas jautājumi ir īpaši aktuāli šobrīd, kad ar tiem saskaramies gan ikdienas dzīvē, izvērtējot ziṇu avotus par aktuālām sabiedrības tēmām, gan plašākā kontekstā, jo vairākas valstis turpina iekšējo informatīvo cenzūru, dezinformācijas radīšanu, apzinātu manipulāciju ar cilvēkiem. Pašreiz, raugoties vēstures zinātnes devumā, var sacīt, ka 1941. gada 14. jūnija deportācijas ir labi izpētītas, fiksēti fakti - gan pavēḷ secība, gan notikumu gaita, balstoties saglabātajā dokumentācijā un aculiecinieku liecībās -, publicēti deportēto saraksti, grāmatās izdoti cietušo atmiṇu stāsti. Latvijas Okupācijas muzeja (LOM) krājumā no 2422 videoliecībām 240 ir šajā akcijā deportēto liecības, papildus vēl daudzās citās filmētajās mutvārdu vēstures intervijās minēts šis notikums un tā sekas cilvēku, viṇa gimenes un tuvinieku dzīvē. Aculiecinieku stāstījumi ḷauj izpētīt, ko zināja vai nezināja Latvijas iedzīvotāji par 1941. gada 14. jūnija deportāciju, kādas bija informētības vai nezināšanas sekas. Pētījuma avotu bāze ir LOM videoliecību kolekcija. Savā ziṇojumā pēc veiktās aculiecinieku vēstījumu analīzes iezīmēju septiṇus deportācijas norises informācijas cirkulācijas un konteksta atslēgpunktus:

1. Slepenās informācijas noplūde: dažu represīvo jeb varas iestāžu darbinieku individuālie lēmumi - deportējamo brīdināšana, ieteikšana bēgt, nebūt mājās.

2. Gatavošanās akcijai: vai cilvēki paši, proti, "vienkāršie ḷaudis”, varēja kaut ko manìt, dzirdēt, zināt pirms deportācijas norises?

3. Informācija izsūtī̌sanas brīdī: kur un kā tiek cilvēki "paṇemti”, kādā valodā, kādā emocionālā tonī ar viṇiem tiek runāts, cik laika sagatavoties, kas viṇiem tiek teikts/neteikts, ko dzird, ko saprot, kā atkarībā no pateiktā un saprastā rīkojas cietušais.

4. Vīriešu nošķiršana un šis nošķ̧iršanas skaidrojumi: apzināta dezinformācija kā represīvās sistēmas nepieciešamība, lai izdotos akcija; kas tika teikts deportētajiem, kā cietušie reageeja, un kādas bija sekas, kā reaǵēja tie nedaudzie vīrieši un viṇu gimenes, kurus nenošḳīra represīvo iestāžu pārstāvju kḷūdas dēḷ.

5. Bēgšanas mēginājumi: stingrās apsardzes dēl un baiḷu iespaidā tie praktiski nebija iespējami, taču ir vairākas liecības gan par neveiksmīgiem, gan veiksmīgiem izglābšanās gadījumiem, turklāt vairāki no tiem saistīti ar Jelgavas staciju.

6. Papildu mantu, pārtikas iedošana vagonā: lai arī deportācija bija slepena akcija, tomēr tad, kad radus, draugus aizveda uz vagoniem, diezgan ātri izplatījās 
ziṇas, kur tiek formēti izsūtīto ešeloni. Dabiska bija tuvinieku vēlme aiziet un aiznest papildu apgèerbu, mantas. Videoliecību krātuvē glabājas stāsti par noḳ̣ūšanu vai nenokḷūšanu līdz šiem vagoniem un papildu mantu saṇemšanu vai nesaņemšanu.

7. Zīlēšanas un sapṇu nozīme: ikvienā vēsturisko pārmaiṇu, neziṇas laikmetā pastiprinās ezoteriskā informācija, kādu noteiktu zīmju un parādību nozīme, kam cilvēks pievērš uzmanību. Arī šì videoliecībās rodamā informācija vēsta par deportāciju uztveri un emocijām, kā arī to ietveršanu konkrētās personas dzīves pašnaratīvā. Piemēram, kāda aculieciniece atcerējās: "Finkam, kā par brīnumu, bija mugurā kažoks, un viṇam bija velteņi siltie padusē. Vai viṇam bija teikts, kur viṇu ved? Bet viņš bija jau nodrošinājies tam Sibīrijas salam, kas mūs visus sagaidīja.” (Inta Prauliṇa, dzim. Ruka (OMF2300/131))

Šajā pētījumā tiek analizētas 30 videoliecības. Intervētās personas ir 1941. gada 14. jūnijā deportētie, kuri izsūtīšanas brīdī bija 15-40 gadu veci. Tajās rodama informācija, kas iekḷaujas visos minētājos septiṇos atslēgpunktos. Tādējādi šie materiāli ir pētāmi ar kvantitatīvo kontentanalīzi, kuras rezultāti l̦aus iezīmēt galvenās apritē esošās informācijas un dezinformācijas tendences. Izraudzìto analizējamo interviju kopu veido pieaugušo vai gandrīz pieaugušu cilvēku liecības, līdz ar to šajā pētījumā netiks aplūkotas bērnu emocionālās traumas un uztveres īpatnības. LOM videoliecību kolekcijā ir tikai viena 1941. gada 14. jūnijā deportētā un uz ieslodzijumu Vjatlagā nosūtītā vīrieša liecība, kas ir kvalificējama kā tematiski atsevišķa unikāla liecība. Līdz ar to pētījumā tiek iztirzāts tikai nometinājumā nonākušo un izdzīvojušo skatījums. LOM krājumā ir arī deportēto, kuri izsūtǐšanas laikā bija bērni un kuri vēlāk neatgriezās Latvijā, bet palika dzìvot Krievijas PFSR, mutvārdu vēstures liecības. Arī šìs liecības pagaidām pētījumā netiek izmantotas. Bez iezīmētajiem septiṇiem atslēgpunktiem tālākā pētniecībā var tikt pievērsta uzmanība arī deportēto informētībai par Vācijas-PSRS kara sākumu, proti, vai viṇi un kā uzzina vai neuzzina par šo notikumu, vai viṇi zina, kas notiek ar atšķirtajiem vīriešiem, kā notiek saziņa, sarakste ar Latvijā palikušajiem radiem, draugiem pēc otrreizējās Latvijas okupācijas, kāda ir informācija par legālo un nelegālo bērnu atgriešanos Latvijā, bēgšanas iespējām, vai 1941. gada deportētie zināja par 1949. gada 25. marta deportāciju, kā cirkulēja informācija par atbrīvošanu un atgriešanos/neatgriešanos Latvijā. Kopumā jau tagad, kad ir veikta tikai daḷa iecerētā pētījuma, var sacìt, ka informētībai un/vai nezināšanai par notiekošo, kas cilvēkam bija izsūtǐšanas laikā 1941. gada 14. jūnijā un tās norises tālākā gaitā, bija būtiska nozīme viņu dzīvē, it īpaši pirmajos nometinājuma gados. Lielākajai daḷai liecību sniedzēju dezinformācijas radītās psihologiskās un emocionālās traumas ir saglabājušās līdz pat mūža nogalei, tādā veidā iespaidojot arī vēlākā dzīvē pieņemtos vai nepieņemtos lēmumus.

Atslēgvārdi: deportācija, informācija, dezinformācija, videoliecība, trauma

\section{Atsauces}

Latvijas Okupācijas muzejs, kolekcijas inv. Nr. OMF 2300. 


\title{
INFORMATION AND DISINFORMATION DURING SOVIET MASS DEPORTATIONS. EXAMPLE OF THE DEPORTATION OF JUNE $14^{\text {TH }} 1941$
}

\author{
Lelde Neimane \\ $\triangle$ lelde.neimane@omf.lv \\ ORCID: https://orcid.org/0000-0002-3960-4536
}

In current times, it is typical that we have a large amount of information available to us and that only the intelligent, knowledge and understanding, among us can avoid confusion. Questions regarding trustworthy sources, of information and disinformation, are current, modern, issues. But what was it like during different historical periods and events, how did people deal with information in the $20^{\text {th }}$ century? A tragic moment in the history of Latvia is the June $14^{\text {th }}, 1941$, mass deportations-the first Soviet mass deportation from the Baltic states. Among all the historical sources related to these events, the different kinds of documents, the registers of deported people, the many autobiographical works of survivor and more, there are also the oral history testimonies of deportees and eyewitnesses in the archives of the $\mathrm{Mu}-$ seum of the Occupation of Latvia. From a total of 2422 video testimonies that have been stored in that Archive, there are 240 testimonies of individuals deported in 1941 as well as the important recollections of eyewitnesses. These testimonials not only allow researchers the opportunity to see this historical event from the perspective of ordinary people, they give us insights into understanding how much, if at all, people knew about the Soviet deportations before June 1941. They allow researchers to observe how much information, and of what kind, was provided during these events and the consequent days. In this abstract, following an analysis of eyewitness accounts, the study highlights seven key points in the circulation and context of the information available regarding the deportation process:

1. Leakage of secret information: warnings of possible deportations from people who worked for the Soviet repressive authorities.

2. Shortly before the deportation: before the events, something suspicious was noticed (wagons, trucks, etc.) and what were people's interpretations of these abnormalities?

3. The information attained during the initial round up of victims from their homes: where and how people were taken, what language were they provided an explanation in, if at all, what was the emotional tone of that explanation, how much time was allotted for them to prepare, what were they told, what they heard and what they understood?

4. The separation of families: Soviet disinformation provided about families, that they would be reunited at the end of the trip, and the consequences of the exceptions that it created.

5. Opportunities for escape: Because of an all-round fear held by the deportees and a strong system to guard them, it was almost impossible to escape from 
the wagons. Yet, there were several possibilities, some attempts and even one successful escapee. Three of the four known testimonies, regarding escape attempts, place them at Jelgava station.

6. Possibilities to provide extra food or clothes to deportees in the wagons from outside: Although the deportation was a secret operation, relatives and friends of deportees noticed what was taking place. The news spread quite quickly, and relatives went to the railway stations to try and provide more food, to take babies from wagons, etc.

7. The importance of foreboding, fortune-telling, cartomancy, dreams: The relevance given to nontraditional information sources, and to the secret meanings of different kind of signs, were not unprecedented in everyday life. Therefore, before and during the deportation, even during the many years in forced resettlements, such sources were often given special attention. For many survivors, they helped them get through their life's darkest hours.

The researcher is currently analysing 30 video testimonies of deportees who were at the age of 15-40 years at the time of their deportation. The main focus in this research is on these seven key moments, but there could be more aspects and moments to be analyzed. For example, if and how deportees came to know about the Germany-USSR war and what did they think about it; how wives got information about their husbands; communication, correspondence, with relatives and friends who remained in Latvia after the second occupation; the legal/illegal return of children to Latvia in 1946; the opportunities for escape; knowledge of those deported in 1941 about the second Soviet mass deportation, of March 25 $5^{\text {th }} 1949$; information that relates to the release of deportees and their return to Latvia. As the Museum's collection of video testimonies about the Deportation of 1941 contains only one interviewee who survived Vyatlag (camp), the researcher has analyzed the testimonies of those people who were in the forced resettlements but not in GULAG camps. Concluding this abstract, it can be noted that the more information people not only knew but truly understood on June $14^{\text {th }}, 1941$, the better prepared they were for the harsh circumstances they faced. The more they understood their fate, the greater were their chances for surviving. This holds true especially in their first years of deportation. Furthermore, it can be said that the psychological and emotional trauma caused by disinformation have been permanent for most of these interviewees, it was often held until the end of their lives.

Keywords: deportation, information, disinformation, video testimony, trauma

\section{References}

The Museum of the Occupation of Latvia, Collection No OMF 2300. 


\title{
INFORMĀCIJA UN DEZINFORMĀCIJA DEPORTĀCIJU LAIKĀ. 1949. GADA 25. MARTA DEPORTĀCIJAS PIEMĒRS
}

\author{
Evita Feldentāle \\ \evita.feldentale@omf.lv \\ ORCID: https://orcid.org/0000-0002-7203-4942
}

Latvijas 20. gadsimta vēsturi tieši ietekmēja politiskie procesi Eiropā, kuru dēl valsts zaudēja savu neatkarību 1940. gadā, kad to, balstoties uz 1939. gada 23. augustā noslēgto Molotova-Ribentropa paktu ar slepeno papildprotokolu, okupēja Padomju Sociālistisko Republiku Savienība (PSRS, arī - Padomju Savienība). Atkārtots Padomju Savienības okupācijas režīms Latvijas teritorijā atsākās 1944./1945. gadā. PSRS okupācijas režīma represiju sistēmas sastāvdaḷa bija arī masveida iedzīvotāju deportācijas 1941. un 1949. gadā. 1949. gada 25. marta deportācijas akcijas, kas saucās "Krasta banga" un vienlaikus norisinājās Latvijas PSR, Lietuvas PSR un Igaunijas PSR, mērḳis bija pabeigt reǵionā sākto sovetizāciju un aktīvās bruṇotās pretestības likvidāciju. 1949. gada 25. martā un turpmākajās dienās no Latvijas teritorijas mūža nometinājumā uz attāliem Krievijas PFSR apgabaliem tika izsūtīti 42125 iedzīvotāji. Tā kā operācija bija iecerēta slepena, ir ḷoti svarīgi novērtēt informācijas apjomu, kas cirkulēja sabiedrībā. Informācijas noplūšanu pavisam noteikti veicināja lielais operācijas īstenošanā iesaistīto cilvēku skaits, tiek lēsts, ka bijuši iesaistīti 76212 cilvēki. Lìdz šim pētījumos apskatīta deportācijas norise visā Latvijā un analizēti dati par atsevišķiem Latvijas regioniem, statistiski aplūkojot to, kas bija deportētie iedzīvotāji, balstoties uz arhīvu lietām par deportācijām. Konferencē prezentētajā referātā kā pamata avots izmantotas videoliecības ar cilvēkiem, kuri bijuši šā vēsturiskā notikuma aculiecinieki vai līdzdalībnieki dažādās pakāpēs, tādā veidā pievēršot uzmanību videoliecībām kā avotam deportāciju pētniecībā, kas vairāk aplūko to informètības un dezinformācijas līmeni, kas valdỉja sabiedrībā, arī starp cilvēkiem, kas bija tieši iesaistīti deportācijas akcijas īstenošanā. Prezentācija sagatavota, balstoties uz Latvijas Okupācijas muzeja (LOM) Audiovizuālo materiālu krātuvē atrodamajām videoliecībām. No kopējā krājuma, kurā ir 2421 videoliecība, 630 videoliecībās intervētie ir piedzīvojuši izsūtīšanu no Latvijas 1949. gada 25. marta deportācijas laikā. Kopējais videoliecību skaits, kurās šì deportācija tiek pieminēta, proti, cilvēki bijuši tās aculiecinieki, līdzdalībnieki vai jau dzimuši nometinājumā deportētajiem cilvēkiem, ir lielāks. Šobrīd šādu liecību skaits vēl nav precīzi fiksēts. Deportācijām kā vēsturiskiem notikumiem uzmanība tiek pievērsta katru gadu, tās vairāk aktualizējot uz deportāciju atceres “apaḷajām” gadadienām. Videoliecību vākšana no cilvēkiem, kuri paši deportēti, piedzīvojuši deportāciju kā aculiecinieki vai bijuši iesaistīti operācijas īstenošanā, ir îpaši aktuāla, jo viṇi jau ir l’oti veci. Paliek arvien mazāk cilvēku, kuri paši var pastāstīt par šiem notikumiem. Attiecīgi tēmas, kas skar deportācijas norisi no aculiecinieku un līdzdalībnieku skatupunkta, nav plaši izvērstas. Mēǵinājums izmantot videoliecỉbas kā avotus paplašina 1949. gada 25. marta deportācijas pētniecības lauku. 
Ziņojumā izmantotās videoliecības rāda, kāda informācija pirms pašas deportācijas norises cirkulēja sabiedrībā, piemēram, Ausma Otīlija Šulce (1933-2007) minēja, ka galvenais nebija deportējamo sarakstā iekḷautais uzvārds, bet kopējais deportējamo skaits, kas bija nepieciešams. Tāpat ir dažādi nostāsti par to, kāpēc kāda ğimene izsūtīta vai - tieši pretēji - izvairījusies no izsūtījuma. Piemēram, Maiga Fridvalde (dz. 1926) stāsta, ka viṇas vīra gimene nav tikusi deportēta, jo tobrīd vīrs atradies dienestā Padomju armijā, kaut arī viṇu gimenes locekḷu vārdi un uzvārdi bija atrodami deportējamo sarakstos. Pašas deportācijas īstenošanas operācijas slepenums izpaudās tā, ka operācijas īstenotāji līdz pat pēdējam brīdim deportācijas īstenošanā iesaistītos cilvēkus neinformēja par to, kas sagaidāms. Tā, piemēram, kravas automašīnas šoferis Arvīds Kazmanis (dz. 1928) stāsta, ka līdz pēdējam brīdim nav zinājis par patiesībā veicamajiem uzdevumiem naktī no 24. uz 25. martu. Uzzinot, kas šajā naktī darāms, viņš baidījies atteikties no uzdevuma izpildes, uztraucoties par savu un savas ǵimenes iespējamu izsūtīšanu. Pretēji rīkojās Pauls Pihelis (1918-2008), kurš izvairijās no došanās uz dzimto Dundagas pagastu, kur viņš tika norīkots kā viens no operācijas īstenotājiem. Pret P. Piheli tika safabricētas apsūdzības, un par nepakḷaušanos rīkojumam viṇam piesprieda divu gadu cietumsodu. Šìs divas epizodes rāda, ka bailes atteikties no pienākumu izpildes tieši varēja ietekmēt cilvēku turpmāko dzīvi. Tāpat bija cilvēki, kas deportācijas brīdī atradās atsevišķi no gimenes, un viṇu liktenis dažās epizodēs bija atšķirīgs. Piemēram, Gunārs Strazdiṇš (1928-2016) brīvprātīgi pieteicās izsūtīšanai, jo cerēja, ka varēs pievienoties savai gimenei. Tā gan nenotika, viṇš ceḷā devās ar pēdējo ešelonu, kurā atradās no dažādām Latvijas vietām pievestie deportējamie cilvēki, kuri deportācijas brīdī nebija kopā ar ğimenēm vai tika vēlāk atrasti, vai līdzīgi kā Gunārs - paši brīvprātīgi pieteicās. Faktors, kas veicināja šo brīvprātīgo pieteikšanos izsūtīšanai, atklāj vēl vienu tēmu, ko būtu nepieciešams padziḷinātāk pētīt, - tā ir sabiedrības attieksme pret cilvēkiem, kas kaut kādā veidā spēja no izsūtỉjuma izvairīties vai arī pieņēma lēmumu brīvprātīgi nepievienoties izsūtītajiem ǵimenes locekḷiem. Piemēram, Vilnis Bergmanis (dz. 1936) stāsta, ka uz mājām regulāri nākuši meklēt kaut ko nelegālu, bet Rusovu gimenes bērni sākotnēji netika pieņemti atpakal̦ skolā, un pieaugušajiem ǵimenes locekḷiem liedza iespēju strādāt. Aplūkojot videoliecības, kurās 1949. gada 25. marta deportācija apskatīta no aculiecinieku vai līdzdalībnieku perspektīvas, redzams, ka tēmu loks, kas iztirzājams, pētot deportāciju, ir plašāks. Viena no mazpētītām tēmām ir sabiedrībai pieejamā informācija un dezinformācija par deportācijas norisi, tās īstenotājiem un upuriem. Tāpat jāturpina iemūžināt 20. gadsimta 40. gadu aculiecinieku vēstījumus, lai viṇu atmiṇas nonāktu vēstures liecību krātuvēs un būtu izmantojamas turpmākajos pētījumos.

Atslēgvārdi: 1949. gada 25. marta deportācija, videoliecības, informācija, dezinformācija, sabiedrība, līdzdalība

\section{Atsauces}

Āboliņa, A. u. c. (2007). Aizvestie. 1949. gada 25. marts. Rīga: Latvijas Valsts arhīvs. 2 sēj. 
Brikmane, E. (2018). 1949. gada 25. martu pieminot. LV portāls. 25. marts. Izgūts no: https:// lvportals.lv/norises/294410-1949-gada-25-martu-pieminot-2018 [skatīts 20.02.2021.]

Latvijas Okupācijas muzeja Audiovizuālo materiālu krātuve (LOM AVK): Gunārs Strazdiņš (LOM 2300/1258); Vilnis Bergmanis (LOM 2300/1000); Berta Rusova, Velta Zadiṇa, Jānis Zadiņš (LOM 2300/0691); Arvīds Kazmanis (LOM 2300/1523); Maiga Fridvalde (LOM 2300/3315); Pauls Pihelis (LOM 2300/0835).

Riekstiņš, J. (2004). Deportēto Latvijas pilsoṇu centieni atgūt zaudēto īpašumu (1953-1959). No: Ērglis, Dz. (sast.). Latvijas Vēsturnieku komisijas raksti. 13. sēj.: Totalitärie okupācijas režìmi Latvijā 1940.-1964. gadā. Latvijas Vēsturnieku komisijas 2003. gada pētījumi. Rīga: Latvijas vēstures institūta apgāds, 510.-537. lpp.

Riekstiņš, J. (2004). 33 ešelonos izsūtītie. Portāls “Noziegumi pret cilvēci”. Izgūts no: http://lpra.vip. lv/33eshel.htm [skatīts 20.02.2021.] 


\title{
INFORMATION AND DISINFORMATION. EXAMPLE OF THE MASS DEPORTATION OF MARCH $25^{\text {TH }}, 1949$
}

\author{
Evita Feldentāle \\ $\triangle$ evita.feldentale@omf.lv \\ ORCID: https://orcid.org/0000-0002-7203-4942
}

The state of Latvia during the $20^{\text {th }}$ of century was directly influenced by the political processes happening throughout Europe. As a result, Latvia lost its independence in 1940, when it was occupied by the Union of Soviet Socialist Republics (USSR, Soviet Union). Latvia was occupied a second time by the USSR in 1944/1945. An important factor of the totalitarian states repressive system was the mass deportations implemented in 1941 and 1949 in the Latvian SSR. The aim of the mass deportation of March 25th 1949 , or operation "Priboi" (operation "Coastal Surf," which was executed at the same time in the Latvian SSR, as in the Lithuanian SSR and Estonian SSR), was to finish the process of "sovietization," initiated already in 1941, and to eliminate the existing armed resistance movement. During the mass deportation of March 1949, 42125 people were deported from the territory of Latvia to Siberia, without the right to return to their motherland. While the operation was meant to be secret, it is important to evaluate the information and disinformation known by society. The amount of information known by society was directly related to the amount of people involved in executing the operation; historians tell us that in the Latvian SSR the number of people involved in the operation was 76212 people. Utilizing archival documents, to date, researchers have looked at the deportation process throughout Latvia and analyzed data on the individual regions of Latvia, statistically looking at the composition of the deported population.

In Latvia, these deportations are commemorated every year. As the age of direct witnesses is growing, gathering testimonies from those people who were deported, experienced deportations as eyewitnesses or had participated in their implementation is important. Less and less people remain who can talk about those events as direct witnesses, as victims or perpetrators of these crimes. Accordingly, the topics of deportation from the point of view of eyewitnesses and accomplices has not garnered wide-rage academic study. Yet, the use of video testimonies as a source expands the research field of the March 25, 1949, deportation, allowing for the inclusion of sources that present the viewpoint of eyewitnesses. The primary sources utilized for the paper presented at the conference were the oral history testimonies available at the Audiovisual archive of the Museum of the Occupation of Latvia. These testimonies contain not only life stories of the deportees but also stories of eyewitnesses and participants. Thus, by focusing on video evidence as a source in deportation research, this study looks at the level of awareness and misinformation that prevailed in society, including among those directly involved in the deportation operation. From a total of 2421 video testimonies in the Museum's archive, approximately 630 testimonies are of the victims of the March $25^{\text {th }}, 1949$, deportation. 
The total number of video testimonies where the deportation of March 1949 is mentioned is not yet fixed, as this number also includes the people who were eyewitnesses, participants, persons who were born at the places of forced resettlement and more.

The video evidence used in this report shows the kinds of information that circulated in society before the deportation itself. For example, Ausma Otîlija Šulce (1933-2007) asserted that the main concern for the authorities was the amount of people, not the names mentioned on the deportation lists. At the same time, there are varying stories as to why families fell victim to, or avoided, deportation. For example, Maiga Fridvalde (b. 1926) claims that the family of her husband was not deported because he was serving in the Soviet Army at the time; while the family name was on the list of deportees, they managed to avoid it. Additionally, the secrecy of the operation was realized by restricting information to those involved in its execution until the very last moment. For example, Arvīds Kazmanis (b. 1928), who was a truck driver, feared what would happen to his family, and himself, if he refused to assist. At the same time, Paulis Pihels (1918-2008) was sentenced to two years in prison for not going to Dundagas parish, where he was meant to participate in the operation. These two episodes show that fear of refusing to participate in the operation could impact the future of individuals and their families. At the same time, there were family members who were not at home on the night of the deportation, resulting in a different destiny. For example, Gunārs Strazdiñ̌s (1928-2016) voluntary applied for deportation because he thought that, in this way, he would be reunited with his family. This did not happen. He was sent off with the last echelon, which housed deportees brought from different parts of Latvia, who were not with their families at the time of deportation and were later found, or, like Gunārs, had volunteered. This bring up one more topic which needs to be researched: the attitude of the state and society to those who avoided deportation or chose not to apply voluntary to meet their family members in forced resettlement. For example, Vilnis Bergmanis (b. 1936) recalled that after his family avoided deportation, they still were subject to regular visits in their home, where the authorities searched for prohibited items. The children of the Rusovs family were not accepted back in school and the adults could not find jobs. By considering the materials available to us in the audiovisual archive of the Museum, materials from the point of view of eyewitnesses or participants, we are able to expand the topics of research in relation to the March 1949 deportation. Not only do such sources provide historical information, they also allow us to concentrate on the aspects of information and disinformation known by society at that time. Parallel to such new fields of research, it remains important that we continue to interview eyewitnesses, that their testimonies are stored in Audiovisual archives for further research.

Keywords: deportation of March 25th 1949 ; videotestimony, information, disinformation, society, participation

\section{References}

Āboliņa, A. u. c. (2007). Aizvestie. 1949. gada 25. marts. Rīga: Latvijas Valsts arhīvs. 2 sēj. 
Brikmane, E. (2018). 1949. gada 25. martu pieminot. LV Portāls. 25. marts. Retrieved from: https:// lvportals.lv/norises/294410-1949-gada-25-martu-pieminot-2018 [viewed on 20.02.2021.]

Latvijas Okupācijas muzeja Audiovizuālo materiālu krātuve (LOM AVK): Gunārs Strazdiņš (LOM 2300/1258); Vilnis Bergmanis (LOM 2300/1000); Berta Rusova, Velta Zadiņa, Jānis Zadiņš (LOM 2300/0691); Arvīds Kazmanis (LOM 2300/1523); Maiga Fridvalde (LOM 2300/3315); Pauls Pihelis (LOM 2300/0835).

Riekstiņš, J. (2004). Deportēto Latvijas pilsoṇu centieni atgūt zaudēto īpašumu (1953-1959). In: Ërglis, Dz. (ed.). Symposium of the Commission of the Historians of Latvia. Vol. 13: Totalitarian Occupation Regimes in Latvia in 1940-1964. Research of the Commission of the Historians of Latvia 2003. Rīga: Latvijas vēstures institūta apgāds. P. 510-537.

Riekstiņš, J. (2004). 33 ešelonos izsūtītie. Portal “Crimes against Humanity. Latvian Site”. Retrieved from: http://lpra.vip.lv/33eshel.htm [viewed on 20.02.2021.] 


\title{
PADOMJU UN NACISTU REPRESIJĀS IZDZĪVOJUŠO G̦IMENES ATMIṆA: REFLEKSIJAS PAR “KARA DZÉMDINĀTO BĒRNU” MUTVĀRDU VĒSTURES LIECĪBĀM
}

\author{
Oskars Gruziņš \\ \o.gruzins@gmail.com \\ ORCID: https://orcid.org/0000-0002-2837-603X
}

Ar jēdzienu "kara dzemdinātie bērni" (children born of war, $C B O W$ ) tiek apzīmēti bērni, kuriem viens no vecākiem ir kādas valsts vietējais iedzīvotājs, bet otrs - pie ārzemju militārajiem spēkiem piederīga persona. Šis fenomens, tagad arī - vesela pētniecības joma, aptver un apvieno ne vien kontinentus, bet arī kontekstus (Lee 2017, 24). Pēckara Latvijā cilvēku bailes un varas terors bija visaptverošs. Par to liecina arī Latvijas "kara dzemdināto bērnu" pētījumā intervēto personu gimeṇu rīcība. No 38 intervijām ar cilvēkiem, kuru tēvi bija Trešā reiha vai Padomju Savienības militārajos spēkos dienoši cilvēki, tikai septini atzina, ka represijās vinuu gimenes nav cietušas. Savukārt 31 intervētais jeb 81,5\% no visiem respondentiem (tostarp $80 \%$ no intervētajiem, kuru gimenēs bija "kara dzemdinātais bērns", kura tēvs padomju militārpersona) stāstijja, ka viṇu giimenes ir skārušas dažādas represijas, tostarp viņu piederīgie tikuši nogalināti.

Šà ziņojuma uzdevums nav iztirzāt "kara dzemdinātos bērnus" kā Latvijas sabiedrības unikālu sociālo grupu. Protams, arī citiem 20. gadsimta 40. gados gan Latvijā, gan ārpus tās dzimušo paaudzes locekḷiem ir savi gimenes vēstures stāsti, kuru sižeta līnijas veido totalitārisma pieredzēto šausmu racionalizācija. Turklāt šajā prezentācijas kopsavilkumā galvenā uzmanība netiek veltīta pašiem izdzīvošanas stāstiem un pieredzētā izskaidrošanai, bet gan tam, kā atmiṇas īpatnības var ietekmēt šos stāstus un ko (ne vien vēstures faktus) var no tiem mācīties. Uzmanības centrā ir represijās izdzīvojušo attiecỉbas ar saviem izdzīvošanas stāstiem un to ietekme uz viṇu identitāti.

Svarīgi ir saprast "vēstures" un "atmiņas" būtisko atšķirību, t. i., atšķirību starp nepielūdzami precīzajiem vēstures faktiem un katra cilvēka identitātē balstīto pagātnes redzējumu. Džeimss Verčs (Wertsch 2002), Aleida Asmane (Assmann 2011), kā arī daudzi citi pētnieki norāda, ka atmiņa gan individuālā, gan kolektīvā līmenī pirmām kārtām ietver identitātei svarīgo pagātnes daḷu. Atškirīīā no vēstures tai piemīt organiska saikne ar vērtībām un piedzīvotajām emocijām. Atminna kā identitātes konstrukcija ir pagātnes saīsinātā versija, ko ietekmē tagadne un nākotnes diktētās vajadzības. Turklāt atmiņa stiprina grupas identitāti, nodrošina sociālās grupas kontinuitāti un kultūras vienotību. Tādējādi atmiṇa ir selektīva, tā var pat akceptēt vēstures izkroplojumus, ignorēt faktus, ja tie ir pretrunā ar identitātes vērtībām un stabilitāti. Tas jāṇem vērā, pētot mutvārdu vēstures, arī Latvijas "kara dzemdināto bērnu", liecỉbas.

Faktiski šĩs pētnieku atziņas par identitātes ietekmi uz mutvārdu vēstures avotiem neapstrīd iespēju šajos materiālos rast patiesas ziṇas par vēstures norisēm, bet 
rosina izsvērt - kādu vēl cita veida informāciju var iegūt no šiem avotiem? Mutvārdu vēstures liecības ietver informāciju, kā indivīdi un grupas atceras vēstures notikumus un kā ar tiem identificējas. Mutvārdu vēstures avoti nav jākvalificē kā nedrošs vēstures avots, bet gan - kā specifisks, apzinoties to saturisko ippatnību un darbam ar tiem izvēloties atbilstošu metodologiju. Pastāvīgi jārēķinās, ka mutvārdu vēstures avoti var būt faktologiski nepilnīgi, pat kḷūdaini un vienlaikus - absolūti "patiesi" to cilvēku un sociālo grupu vērtējumā, kuru identitāte balstās šajos pagātnes stāstos.

Cilvēka psihologijai piemīt tendence veidot jēgpilnas saites starp pirmajā redzējumā šḳietami nesaistīto. Psihologs Klauss Konrāds (Conrad 1958) šai parādībai devis apzīmējumu "apofēnija” (apophenia). Vēlāk, it īpaši, ja represijām bijusi liela ietekme uz cilvēka dzīvi, viņš/viņa mēdz meklēt notikušā racionālu skaidrojumu, turklāt arī tad, ja tā nav. Jans-Viljems van Proje (van Prooijen) un Kārena M. Duglasa (Douglas) savā darbā "Conspiracy Theories as Part of History" (2017) aplūko saikni starp sociālajām krīzes situācijām un ticību sazvērestības teorijām. Viṇi ar daudziem piemēriem ilustrē, kā krīze veicina ticību sazvērestības teorijām. Pētnieki uzsver: cilvēku psihologiskā stāvokḷa liecības vēsta, ka krīzes laikā piedzīvotās negatīvās sajūtas - nenoteiktība, bailes, nespēja kontrolēt notiekošo - rada vēlmi atrast situācijas skaidrojumu. Tādējādi krīze izteikti pastiprina aplamu un melīgu skaidrojumu un sazvērestību izplatību. J.-V. van Proje un K. M. Duglasa arī norāda, ka krīzes periodā tapušās sazvērestību teorijas ar laiku var pārtapt par vēstures naratīviem, kas pa dažādiem kultūras kanāliem izplatās un iesakṇojas sabiedrībā vai noteiktās sociālajās grupās.

Arī Latvijas "kara dzemdināto bērnu" ǵimeņu atmiṇu stāstos par izdzīvošanu un vajāšanām totalitārismā var vērot nozīmīgu traumatisku notikumu racionalizāciju. Lai gan šie skaidrojumi nav vienādojami ar sazvērestības teorijām, tomēr ir konstatējamas atsevišķas līdzības. Jāatzīst, ka Latvijas "kara dzemdināto bērnu" gimeṇu atmiṇā vērojama slieksme vēlāk piedzīvoto milzīgo krīzi nepamatoti racionalizēt. Šāda satura stāsti tiešām var izskaidrot izdzīvošanu nevis kā nejaušỉbu, bet gan kā konkrētā cēlonī sakṇotu notikumu. Vienlaikus nevar apgalvot, ka visi izdzīvošanas un/vai vajāšanu skaidrojumi ir nepatiesi, tomēr atbilžu meklējumi par šiem ğimenēm ārkārtīgi svarīgajiem notikumiem diktē racionalizācijas nepieciešamību, neraugoties uz pierādījumu un patiesi drošu faktu trūkumu. Turklāt šì racionalizācija pārsvarā tiek veikta, lai apstiprinātu šis grupas identitāti. Tādā veidā šādi izdzīvošanas un/vai vajāšanas stāsti dažkārt pārtop par normatīviem nostāstiem jeb leǵendām, kas stiprina grupas un/vai individuālo identitāti. Nostāsti, ar kuru palīdzību norisinās pagātnes izpratne, ir atstājuši un turpina atstāt būtisku ietekmi uz "karā dzemdināto bērnu" gimeņu dzīvi un identitāti. Domājams, ka tiem būs liela nozīme arī nākotnē, jo šie nostāsti ir integrēti ǵimeṇu atmiṇā. Neraugoties uz to, vai šìs atmiṇas par izdzivošanu ir patiesas vai nepatiesas, tās tiek nodotas tālāk un tiek kopdalītas ǵimenei piederīgo atmin̦as grupā. Tādējādi ar to starpniecību šīs grupas locekḷi saprot pagātni, lieto savu identitāti un definē savu nākotnes rīcību. Atmiņas par izdzīvošanu un pieredzētajām šausmām totalitārismā neatkarīgi no to zinātniskā apstiprinājuma vai noraidījuma funkcionē kā ğimeṇu un indivīdu identitātes daḷa. 
Veicot promocijas darba par "kara dzemdinātajiem bērniem” Latvijā pētījumu, praktiski nav iespējams identificēt pret konkrēto gimeni vērsto represiju cēloni. Nav iespējams noteikt, vai tās ir piemērotas tieši tāpēc, ka bērna tēvs ir bijis piederīgs pie nacistiskās Vācijas militārajiem spēkiem vai arī gímene, kurā ir "kara dzemdinātais bērns”, vienkārši tika pakḷauta masveida represijām tāpat kā daudzas citas sociālajā un materiālajā stāvoklī līdzīgas gimenes, proti, bez kāda konkrēta iemesla. Tāpat nav iespējams apgalvot, ka g̊imene tika pasargāta no represijām, jo bērna izcelsme tika slēpta. Taču var apgalvot, ka gimenē rastie/izdomātie notikušā skaidrojumi ietekmēja to identitāti un turpmāko rīcỉbu. Nav atrasti pilnīgi droši un faktos pamatoti pierādījumi, ka "karā dzemdināto bērnu" gimenes tika represētas tāpēc, ka bērna tēvs bija vācu militārpersona. Taču lielākā daḷa intervēto "kara dzemdināto bērnu” ir pārliecināti: ja viṇu slēptā izcelsme tiktu atmaskota, gimene tiktu represēta. Tāpēc tajās ǵimenēs, kurās faktu par bērna tēvu - vācu militārpersonu - sekmīgi slēpa no padomju valsts administrācijas, piemēram, viltojot dzimšanas datus, lielākoties valda pārliecība, ka šì rīcība viṇus visus glāba no represijām.

Atslēgvārdi: "karā dzemdinātie bērni", totalitārisms, ǵimenes atmiṇa, trauma, krīzes situācija

\section{Atsauces}

Assmann, A. (2011). Cultural Memory and Western Civilization. Cambridge: Cambridge University Press.

Conrad, K. (1958). Die Beginnende Schizophrenie: Versuch einer Gestaltanalyse des Wahns [The Onset of Schizophrenia: an Attempt to form an Analysis of Delusion]. Stuttgart: Thieme.

Lee, S. (2017). Children Born of War in the Twentieth Century. Manchester: Manchester University Press.

LOM: Latvijas Okupācijas muzeja Audiovizuālo materiālu krātuve. "Kara dzemdināto bērnu" interviju kolekcija (LOM 2300/3237-3239; 3250-3253; 3288-3290; 3350e; 3351e; 3352e; 3353e; 3354e; 3355e.; 3356e; 3357e; 3358e; 3359e; 3360e; 3361e; 3362e; 3363e; 3364e; 3365e; 3366e; 3368e; 3369e; 3370e; 3371e; 3372e; 3373e; 3374e; 3375e; 3376e; 3381e; 3387e; 3388e; 3389e; 3390e; 3391e; 3392e; 3394e; 3396e; 3405e; 3406e; 3407e). Intervijas veicis Oskars Gruzin̄š un Aivars Reinholds 2016.-2019. gadā Eiropas Savienības “Horizon 2020" Marijas SklodovskasKirī inovatīvā pētniecības un mācību tìkla ietvaros, granta Nr. 642571.

Prooijen, J.-W. van, Douglas, K. M. (2017). Conspiracy Theories as Part of History: The Role of Societal Crisis Situations. Memory Studies, 10(3), 323-333. DOI:10.1177/1750698017701615

Wertsch, J. V. (2002) Voices of Collective Remembering. New York: Cambridge University Press. 


\title{
FAMILY MEMORIES OF SURVIVAL \\ IN THE PERIOD OF SOVIET AND NAZI \\ REPRESSION: REFLECTIONS ON THE \\ ORAL HISTORY TESTIMONIES OF LATVIAN "CHILDREN BORN OF WAR"
}

\author{
Oskars Gruziņš \\ $\bigotimes$ o.gruzins@gmail.com \\ ORCID: https://orcid.org/0000-0002-2837-603X
}

Children born of war (CBOW) are defined as children who are born to a local parent and a member of a foreign military force. This is a phenomenon, and now also a field of study, that spans continents as well as contexts (Lee 2017, 24). In postwar Latvia fear and terror was all-encompassing: of all the subjects of the study of CBOW in Latvia, from a total of 38 interviews of children of Third Reich (TR) and Soviet (USSR) fathers, only 7 reported no repressions in their families. In other words, 31 subjects, or $81.5 \%$ (this includes $80 \%$ of the USSR CBOW subjects), reported state-led repressions, including murders, in their families. In a sense, this abstract will not be looking at a phenomenon unique to CBOW in Latvia. That is, family stories and rationalizations of surviving the horrors of totalitarianism can, no doubt, be observed in other individuals of the same age cohort in Latvia and beyond. Moreover, this summary will not focus on the stories and rationalizations of survival themselves but on how such stories may be impacted by the peculiarities of memory and what, other than historical facts, may be learned from such stories. That is, the specifics of survival stories will not be discussed but their relationship to, and possible impact on, identity will.

In this process, the essential distinction between history and memory must be made; the difference between the cold hard facts of the past and a vison of the past intrinsically linked to identity. James Wertsch (2002) and Aleida Assmann (2011), as well as other researchers, tell us that memory pertains to visions of the past linked to an identity construction, be it that of an individual or a group; unlike history, memory has an organic connection to values and claims with emotional investment. As an identity construction, memory is an abridged version of the past, impacted by the present and motivated by the needs of the future. Furthermore, memory sustains a group's identity, making group continuity and cultural cohesion possible. For this goal, memory is selective and runs the risk of distortions, even ignoring facts, for the stability of identity. Such are the sources that oral history studies, such as CBOW in Latvia, rely on. Essentiality, this brief discussion of how identities may affect oral history sources is not meant to question the ability of such sources to provide historical information, rather it is to highlight the other kinds of information that such sources may provide. It is done to show how such sources may offer important information not only on the events of the past themselves but on how individuals and groups have come to remember and identify with such 
events. It is done not to cast a shadow on oral history testimonies as a source but to highlight the difference between the facts of history and the facts of memory. To bring a recognition that stories which may not be completely factual, nor verifiable, are nonetheless 'true' to the individuals and groups that identify with them.

A tendency in human psychology to perceive meaningful connections between seemingly unrelated things, has come to be coined apophenia by psychologist Klaus Conrad (1958). In hindsight, especially for events of great significance in our lives, humans tend to look for rational where it doesn't necessarily exist. In their work, Conspiracy Theories as Part of History, Jan-Willem van Prooijen and Karen M. Douglas (2017) discuss the link between societal crisis situations and a belief in conspiracy theories. They illustrate how societal crisis situations stimulate a belief in conspiracy theories. They point to psychological evidence suggesting that the adverse feelings that people experience when in crisis - uncertainty, fear and a lack of control - motivate a need to make sense of the situation. Thus, such crisis increases the likelihood of false rationalizations, of conspiracies. Furthermore, they tell us that, after being formed, conspiracy theories can become historical narratives that may spread through cultural transmission in society and groups.

Similarly, stories of survival or persecution in Latvian CBOW family memories, in hindsight, often try to rationalize traumatic events of great importance. While, of course, these rationalizations are different from a conspiracy theory, the inherent similarities should also be noted. It should be recognized that, in a similar way, immense crisis to the family memory group makes unfounded, after-the-fact, rationalizations more likely. That, such stories may explain inexplicable survival not on pure chance, as may be the truth of the matter, but on some other more rational forces. Not to say that rationalizations for survival and persecution cannot be true but that such immensely important events in the family require explanation and, when the gaps in understanding are left to be filled in, when rationalizations are made despite a lack of evidence, it is done in ways that confirm group identity. Thus, such stories often become normative tales that reinforce group and individual identity. Tales that seek to make sense of a past that has had such immense repercussions on their present and can be incorporated into family memory for the sake of that group's future. And, true or false, these memories of survival, as they are transmitted and shared in the family memory group, come to be a part of that groups understanding of its past, a part of its identity and an influence on future behavior. Whatever the case, whether the rational for surviving the horrors of totalitarianism can be academically verified or debunked, such stories of survival and persecution become a part of those families and individuals' identity.

Thus, for the purposes of the larger PhD study of CBOW in Latvia, it is practically impossible to distinguish if certain repressions against the family or child took place because of their TR origins, as some subjects rationalize, or if it was due to the pure randomness of the widespread repressions that the Soviet Union inflicted. Likewise, it practically impossible to identify if no repressions were experienced because the origins of the child were hidden. Nonetheless, it can be said that oftentimes these perceptions and rationalization effected family group identity and future behavior. That is, while the study has not found any definitive proof that 
the regime conducted repressions against TR CBOW or families for the sole fact of their father's origins, many TR CBOW experienced a very real perception that if exposed they would be the target of repressions. Therefore, it can be observed that TR CBOW who had their past hidden from the state, through erroneous information on their birth certificates for example, often credit such deceptions of the state as the reason that they avoided repressions.

Keywords: children born of war, totalitarianism, family memory, trauma, crisis situations

\section{References}

Assmann, A. (2011). Cultural Memory and Western Civilization. Cambridge: Cambridge University Press.

Conrad, K. (1958). Die Beginnende Schizophrenie: Versuch einer Gestaltanalyse des Wahns [The Onset of Schizophrenia: an Attempt to form an Analysis of Delusion]. Stuttgart: Thieme.

Lee, S. (2017). Children Born of War in the Twentieth Century. Manchester: Manchester University Press.

LOM: Museum of the Occupation of Latvia Audiovisual material archive. CBOW interview collection (LOM 2300/3237-3239; 3250-3253; 3288-3290; 3350e; 3351e; 3352e; 3353e; 3354e; 3355e.; 3356e; 3357e; 3358e; 3359e; 3360e; 3361e; 3362e; 3363e; 3364e; 3365e; 3366e; 3368e; 3369e; 3370e; 3371e; 3372e; 3373e; 3374e; 3375e; 3376e; 3381e; 3387e; 3388e; 3389e; 3390e; 3391e; 3392e; 3394e; 3396e; 3405e; 3406e; 3407e). Interviews recorded by Oskars Gruziñš and Aivars Reinholds 2016-2019 in accordance with European Union's Horizon 2020 research and innovation program under the Marie Sklodowska-Curie grant agreement No 642571.

Prooijen, J.-W. van, Douglas, K. M. (2017). "Conspiracy Theories as Part of History: The Role of Societal Crisis Situations”. Memory Studies, 10(3), 323-333. DOI:10.1177/1750698017701615

Wertsch, J. V. (2002) Voices of Collective Remembering. New York: Cambridge University Press. 


\title{
PRESES IZDEVUMI KĀ DEZINFORMĀCIJAS INSTRUMENTS LATVIJĀ UN TRIMDĀ (20. GADSIMTA 50.-60. GADI)
}

\author{
Viesturs Zanders \\ $\bigotimes$ viesturs.zanders@lu.lv \\ ORCID: https://orcid.org/0000-0002-4231-840X
}

Latvijas jaunāko laiku mediju vēstures atsevišķu posmu un problēmu izpēte vēl joprojām ir aktuāla. Tikai detalizēta publicēto avotu un dokumentārā mantojuma analīze lauj iespējami pilnvērtīgi analizēt procesus un personības padomju okupētajā Latvijā, tostarp skaidrojot un izvērtējot ar mediju vidi saistīto personu rīcības motivāciju un viṇu darbības faktiskos rezultātus. Nereti tie nozīmīgi atškiras no publiskajā telpā atrodamajiem subjektīvakiem pieņēmumiem un leǵendām, kam piešķirts vispārinājuma statuss. Krievijas dezinformācijas politika ir neatņemama tās geopolitisko interešu īstenošanas sastāvdaḷa. Tai ir vērā ņemama un pietiekami efektīva pieredze, kas iegūta padomju varas gados. Neraugoties uz būtiski mainījušos mediju vidi pēdējos gadu desmitos, ir pamats uzskatīt, ka Krievija vēl arvien izmanto jau agrāk aprobētas dezinformācijas metodes un, iespējams, padomju laika dezinformācijā iesaistītas vai tās iespaidotas personības. Digitalizēto preses izdevumu pieejamība nodrošina ne tikai jaunas pētniecības iespējas dezinformācijas atpazī̌sanai un apkarošanai, bet arī vēl plašākas dezinformācijas izplatīšanas iespējas, jaunām manipulācijām par materiālu izmantojot padomju laika presē publicētos melus un puspatiesības. Pēdējos gados pieaug pētījumu skaits par Krievijas ietekmi Latvijas informatīvajā telpā. Vēl aizvien okupētās Latvijas un trimdas mijiedarbe visdažādākajās jomās ir pētīta gan padziḷināti, tomēr samērā fragmentāri (vēsturnieks Andrievs Ezergailis, valodniece Lilita Zaļkalne, literatūrvēsturniece Eva Eglāja-Kristsone u. c.). Tēmas izpētes nolūkos esmu detalizēti iepazinies ar nozīmīgākajiem latviešu trimdas preses izdevumiem ("Laiks", "Latvija", "Latvija Amerikā" u. c.) un okupētās Latvijas laikrakstiem ("Par Atgriešanos Dzimtenē", "Dzimtenes Balss”), kā arī atsevišḳu trimdas zinātnieku un kultūras darbinieku arhīvu materiāliem (Haralda Biezā un Žaṇa Unāma fondi Latvijas Nacionālajā bibliotēkā, Pētera Aigara un Aleksandra Plensnera fondi Latvijas Universitātes Akadēmiskajā bibliotēkā).

Padomju propagandas iestādes ar preses izdevumu starpniecību centās veicināt trimdas latviešu repatriāciju, diskreditēt politiski aktīvos trimdiniekus un padziḷināt trimdas sabiedrībā objektīvi pastāvošās pretrunas. Lai īstenotu savus mērḳus, padomju iestādes izmantoja dažādus kanālus: finansiāli un saturiski nodrošināja atsevišķu ārpus Latvijas iznākošu preses izdevumu pastāvēšanu ("Amerikas Vēstnesis", "Viesis" Austrālijā, Eduarda Alaiṇa izdevumi VFR), mēgināja ietekmēt vairāku trimdas periodisko izdevumu (žurnāli “Tilts", "Jaunā Gaita”) redakcionālo politiku. Taču viskoncentrētāk un ilgstošāk (1958-1989) trimdas sabiedrības šķelšanu veicināja laikraksts "Dzimtenes Balss,” kuru izdeva Valsts drošības komitejas satelītorganizācija Latvijas komiteja kultūras sakariem ar tautiešiem ārzemēs. 
Regulāri laikrakstā tika iespiestas padomju represīvo iestāžu pasūtīuma publikācijas, butaforiski neīsti Latvijas realitātes apraksti. "Dzimtenes Balss" mēǵināja radīt ilūziju par radošo brīvību un latviešu trimdas izdevumu pieejamību Latvijā. Pašreizējā izpētes pakāpe ḷauj secināt, ka padomju subsidēto un ārpus Latvijas izplatīto preses izdevumu nozīme bija margināla, tiem bija minimāli panākumi padomju varai sevišksi nevēlamu personu diskreditācijā. Tomēr nevar noliegt, ka padomju dezinformācija atstāja savu iespaidu uz trimdas preses atklātības pakāpi, jūtami sašaurināja analītiskas kritikas iespējas, respektīvi, reālu preses brīvību. Politiski aktīvā latviešu trimdas sabiedrības daḷa centās mazināt padomju dezinformācijas ietekmi, gan mēǵinot ierobežot padomju propagandas izdevumu izplatību, gan radot tai alternatīvus informācijas resursus. Ja apzināmies, ka Latvijas valstiskums nav pašsaprotams un neapdraudēts, nepietiek ar secinājumu, ka mūsu vēsturiskā pieredze Latvijai sniedz zināmas priekšrocības cīṇā pret Krievijas dezinformācijas kampañām. Tā ir izmantojama arī Latvijas jaunāko laiku vēstures pētniecībā un sabiedrības izglītošanā.

Atslēgvārdi: padomju propaganda, dezinformācija, laikraksts "Dzimtenes Balss", preses izdevumi, trimdas latviešu sabiedrība

\section{Atsauces}

Eglāja-Kristsone, E. (2013). Dzelzsgriezēji: Latvijas un Rietumu trimdas rakstnieku kontakti. [Rīga]: Latvijas Universitātes Literatūras, folkloras un mākslas institūts.

Lešinskis, I. (2017). Starp divām pasaulēm: kalpības gadi un citi raksti, sast. Ieva Lešinska. [Rīga]: Domas spēks.

Zaḷkalne, L. (2014). Back to the Motherland: Repatriation and Latvian Émigrés 1955-1958. Stockholm: Stockholm University. 


\title{
PRESS PUBLICATIONS AS A MEANS OF DISINFORMATION IN LATVIA AND IN LATVIAN EXILE COMMUNITIES (THE 1950s AND 1960s)
}

\author{
Viesturs Zanders \\ $\triangle$ viesturs.zanders@lu.lv \\ ORCID: https://orcid.org/0000-0002-4231-840X
}

Exploring specific periods and problems in the recent history of media in Latvia has not lost its actuality. Only detailed analysis of published sources, as well as documentary heritage, makes it possible to attain a fully-fledged understanding of the processes and personalities in Soviet occupied Latvia. This includes clarifying and estimating the motivations of the figures connected with the media as well as the real results of their activities. Quite often one can find mismatches between the real situation and of subjective assumptions, even legends, circulating in public discourse which nevertheless have a status of general knowledge. The policy of disinformation realized by Russia today is an integral part of achieving its geopolitical interests. In this respect, Russia can use the considerable, and quite effective, experience gained in the USSR. Despite significant changes of the media landscape, there are reasons to believe that during the last decades Russia has continued to use the disinformation techniques of its past, as well as the individuals who were involved in the Soviet era disinformation campaigns and those who are still under their influence. The availability of digitized versions of the printed press provides not only new research possibilities aiming to recognize and counteract disinformation but also - no matter how strange it may sound - those that assist in the dissemination of disinformation. Namely untruths and half-truths published in the Soviet era can be used for fresh manipulations. In recent years, there is a growing number of studies concerning Russia's influence on the informative space in Latvia. However, while the interactions between the communities in occupied Latvia and those in exile are now being researched in more depth, this is still done in a fragmentary way (historian Andrievs Ezergailis, linguist Lilita Zalıalne, literary historian Eva Eglāja-Kristsone and other). By exploring this topic, detailed insights on the most significant press publications of the Latvian communities in exile have been attained (Laiks, Latvija, Latvija Amerikā u.c.), as well as from the newssheets in occupied Latvia (Par Atgriešanos Dzimtenē, Dzimtenes Balss) and from the archives of several scientists and public intellectuals in exile (funds of Haralds Biezais and Žanis Unāms in Latvian National library, funds of Pēteris Aigars and Aleksandrs Plensners in Academic library of Latvian University).

The Soviet propaganda machinery used press publications in its efforts to encourage repatriation, to discredit the politically active members of the exiled communities and to deepen the internal contradictions inherent in the communities of those exiled. To achieve these goals different channels were used: the provision of financial and content support to several newssheets published outside Latvia 
(Amerikas Vēstnesis (USA), Viesis (Australia), papers published by Eduards Alainis (the Federal Republic of Germany)), as well as by trying to influence the editorial policy of some periodicals in exile (magazines Tilts, Jaunā Gaita). However, the most insistent and lasting (1958-1989) efforts to split the communities in exile were made by the sate run newspaper Dzimtenes Balss, which was published by a satellite organization of the KGB, the Latvian Committee for Cultural Relation with Countrymen abroad (1958-1989). The newspaper regularly published texts imposed by the Soviet repressive authorities, including fake descriptions of life in Soviet Latvia. Dzimtenes Balss aspired to create an illusion about creative freedoms in Latvia and the availability of materials published in exile. The current level of research allows one to conclude that the impact of the press publications subsidized and distributed outside Latvia by the Soviet authorities was marginal. And, that the efforts to discredit some persons unacceptable to Communist power were of minimal success. However, one cannot deny, that Soviet disinformation had some influence concerning the degree of media freedom in the communities in exile, e.g. narrowing significantly the capability for critical analyses, thereby abating real press freedom. The politically active fraction of Latvian society in exile tried to reduce the influence of Soviet disinformation - seeking to restrict the distribution of Soviet propaganda publications as well as creating alternative information resources. Considering that the statehood of Latvia is not an absolute certainty, that our nation is not completely safe, it is not enough to simply declare that historical experience gives Latvia some advantage in the battle with Russian disinformation campaigns. This experience must also be used in educating the public and when exploring recent events.

Keywords: Soviet propaganda, disinformation, the newspaper Dzimtenes Balss, press publications, Latvian communities in exile

\section{References}

Eglāja-Kristsone, E. (2013). Dzelzsgriezēji: Latvijas un Rietumu trimdas rakstnieku kontakti. [Rīga]: Latvijas Universitātes Literatūras, folkloras un mākslas institūts.

Lešinskis, I. (2017). Starp divām pasaulēm: kalpības gadi un citi raksti, sast. Ieva Lešinska. [Rīga]: Domas spēks.

Zalıkalne, L. (2014). Back to the Motherland: Repatriation and Latvian Émigrés 1955-1958. Stockholm: Stockholm University. 


\section{MELU DAUDZVEIDĪBA UN ĒTIKA}

\section{Skaidrīte Lasmane}

$\bigotimes$ skaidrite.lasmane@lu.lv

ORCID: https://orcid.org/0000-0002-2827-0470

Dezinformācijas un sazvērestību pētniecību tradicionālajos un digitālajos medijos padara skaidrāku un atvieglo ikdienā un kultūrā plaši lietotais melu jēdziens. Meli ir nepatiesas, sagrozītas un maldinošas informācijas komunikācija. Kā komunikatīvs un izteikti interaktīvs fenomens meli pastāv ar nolūku pārliecināt un ietekmēt. Melu kaitējums un bīstamība demokrātijai izpaužas dezorientējošā iedarbībā, proti, brīvas un autonomas lemšanas un komunikācijas deformācijā. Kaut gan meli deformē īstenības godīgu, patiesu un uzticamu atveidojumu, tomēr to publisks lietojums, izplatība un ietekme gan vēsturē, gan mūsdienās atzīstama par ievērojamu. Uz to norādījis vācu filozofs Frīdrihs Niče (Friedrich Nietzsche), saskatot melu komunikatīvā un ietekmējošā spēka cēloni ne tikai dezinformējošā darbībā un sazvērestību vērpšanā, bet arī cilvēka aklā gatavībā ticēt un nepārvaramajā tieksmē tikt maldinātam (Nīče 2007, 57). Gatavībai ticēt un atzīt dezinformāciju par patiesu seko atbilstoša rīcība, kas apgrūtina mediju un sociālās ekosistēmas stabilitāti un attīstības iespējas. Tāpēc pētniecībā ir svarīgs gan atsevišķu melīgu veidojumu un safabricējumu atmaskojums, gan vispārinošas zināšanas attiecībā uz melu arhitektūru un funkcionēšanu sabiedrībā. Melu interaktīvais, komunikatīvais aspekts aplūkojams gan no individuāla, organizācijas vai kolektīva melu sniedzēja, gan no adresāta ticības un gatavības sekot meliem, tos atbalstot. "Kāda ir atšķirība starp pārliecināto un apmānīto?" jautā Nīče un atbild: "Nekāda, ja vien viṇš ir labi apmānìts." (Nīče 2007, 5)

N̦emot vērā melu bīstamo deformējošo efektu un kaitniecisko ietekmi uz uzticamu un brīvu komunikāciju, melu konstatējumam un atmaskojumam palīgā saukta zinātne un tehnika. Tā, piemēram, Džeimsa Makenzī (James Mackenzie, 1853-1925) melu detektors (1899-1900) ar nepārtrauktiem uzlabojumiem ir kalpojis patiesības noskaidrošanai. Mūsdienās, kad, pateicoties interneta un sociālo tīklu komunikācijai, paplašinās arī nepatiesas un maldinošas informācijas izplatīšana, kas īpaši bīstama krīzes situācijās, melu izplatībai ar dažādām sekmēm seko gan interneta platformas (YouTube, Facebook u. c.) un mediju ziņu dienesti (LSM.lv), gan globāli un atsevišķu valstu faktu pārbaudes institūti. Latvijā melīgu faktu un apgalvojumu dezinformējošo ietekmi cenšas mazināt Re:Baltica faktu pārbaudes un sociālo tīklu pētniecības laboratorija Re:Check, Ārlietu ministrijas Stratēgiskās komunikācijas projektu grupa, LSM.lv un citas institūcijas. Kas attiecas uz atsevišķu nepatiesu un melīgu faktu pārbaudi, dažkārt pētniecībā gan apšaubìts to efekts: viltus ziṇu izplatīšanās ātrums un ietekme nav salīdzināma ar post factum patiesības skaidrošanas ilgumu, kā to pierāda ASV prezidenta Donalda Trampa (Donald Trump) gadijums (Skewes 2018).

Projekta "Dezinformācijas un sazvērestību radītie riski demokrātijai: Latvijas pieredzes pārlūkošana” ietvarā referātā pievērsta uzmanība melu daudzveidỉbai un to morālajam vērtējumam. Vienlaikus akcentēta problēma, kā pētniecībā vājināt 
un novērst melu ietekmi, atsevišķu gadijumu analīzi papildinot ar izaicinājumu identificēt jaunas melu transformācijas un funkcionēšanu digitālajā demokrātijā. Referātā analizētas divas melu iedarbības izpausmes - melu neitralizācija un melu normalizācija. Melu normalizācija, veidojot pieradumu, apgrūtina melu neitralizāciju. Melu normalizācijas sakarā uzsvērta, pirmkārt, lingvistiska stratēgija, īpaši eifēmismu izmantošana, lai apslēptu melu bīstamo saturu; otrkārt, melu atkārtošana, pieradinot pie sagrozītas patiesības; treškārt, noklusējot melu morālās un demokrātijai bīstamās sekas un efektu. Melu ietekmes neitralizācijas kopsakarā uzsvērta pirmām kārtām melu arhitektūras un komunikācijas izziṇa, atseviškłu gadījumu padziḷināta analīze, kā arī mediju pratības un vispārējā intelektuālā līmeṇa un izglītošanas loma sabiedrībā. Analizējot dezinformācijas ētiku, pievērsta uzmanība melu daudzveidībai. Pētniecībā norādīts uz 34 empīriskiem gadỉjumiem, kas kvalificējami kā viltus ziṇas, tostarp apzināti safabricēts saturs, foto manipulācijas, reklāmas materiāls, propagandas maldinājums, parodija utt. (Tandoc et al. 2018). Blakus apzinātai bīstamu melu izplatīšanai minami ambivalenti vērtējamie pieḷaujamie meli, ja tie sniedz īslaicīgu pragmatisku labumu indivīdam (glābjošie meli veselības aprūpē) vai sabiedrībai (mazina paniku krīzes gadījumā, atvieglo policijas darbību noziegumu izmeklēšanā) u. c. Melu morālā aspekta skaidrojumam izmantojama daudzdimensionāla pieeja, pievēršot uzmanību gan nepatiesajam saturam, krāpnieciskajam un maldinošajam nodomam, īpaši partiju populismā un vēlēšanu kampaṇā, gan maldinošai funkcionēšanai un nekritiskai pieņemšanai un tālāk izplatǐšanai medijos.

Atslēgvārdi: meli, melu daudzveidība, melu verifikācija, melu normalizācija, melu neitralizācija

\section{Atsauces}

Nīče, F. (2007). Melošanas māksla. Pārdomas un aforismi. Rīga: Zvaigzne ABC.

Skewes, E. (2018). Time Delays are Not Enough; Media must Call Out Lies. Journal of Media Ethics, 33(2), 97-99. DOI:10.1080/23736992.2018.1435498

Stroud, S. R. (2019). Pragmatist Media Ethics and the Challenges of Fake News. Journal of Media Ethics, 34(4), 178-192. DOI: 10.1080/23736992.2019.1672554

Tandoc, E. C., Lim, Z. W., Ling, R. (2018). Defining "Fake News" A Typology of Scholarly Definitions. Digital Journalism, 6(2), 137-153. DOI: 10.1080/21670811.2017.1360143 


\title{
THE DIVERSITY AND ETHICS OF LIES
}

\author{
Skaidrīte Lasmane \\ $\bigotimes$ skaidrite.lasmane@lu.lv \\ ORCID: https://orcid.org/0000-0002-2827-0470
}

Research on disinformation and conspiracy in traditional and digital media clarifies and facilitates the notion of lies, which is widely used in everyday vernacular and cultural life. Lies are the communication of false, distorted and misleading information. As a communicative and highly interactive phenomenon, lies exist with the intent to persuade and influence. The damage and danger to democracy of lies manifests in its disorienting effects, namely the distortion of free and autonomous decision-making and communication. Although lies distort the fair, truthful and reliable representation of reality, their public use, prevalence and influence, both historically and today, are significant. This has been noted by the German philosopher Friedrich Nietzsche, in his observations of the communicative and influential power of lies not only in disinformation and the development of conspiracies, but also in the individual's blind readiness to believe and in their insurmountable tendency to be deceived (Niče 2007, 57). The willingness to believe and acknowledge misinformation as true is followed by appropriate action, which hampers the stability and development potential of the media and the social ecosystem. Therefore, it is important for research to expose both false formations and fabrications, as well as provide general knowledge about the architecture and functioning of lies in society. The interactive, communicative, aspect of lies can be viewed both from the individual, organizational or collective provider of lies, as well as from the recipient's faith and readiness to follow the lies by supporting them. "What is the difference between a confident and a deceived person?" Nietzsche asks and replies, "Nothing unless he is well deceived" (Niče 2007, 5).

Given the dangerous distorting effects of lies, and their detrimental effects on reliable and free communication, science and technology have been used to help detect and expose lies. For example, James Mackenzie's (1853-1925) lie detector (1899-1900), with continuous improvements, serves to clarify the truth. Nowadays, when the dissemination of false and misleading information, which is especially dangerous in crisis situations, is expanding thanks to internet and social network communication, the spread of lies and their repercussion is monitored by numerous internet platforms (YouTube, Facebook, etc.), media news services (LSM.lv) and both global and national fact-finding institutes. In Latvia, Re: Baltica fact-checking and social network research laboratory Re: Check, the Strategic Communication Project Group of the Ministry of Foreign Affairs, LSM.lv news analysis and other formations try to reduce the effects of disinformation, false facts and allegations. As for the examination and exposure of certain false facts and lies, research has sometimes questioned its effectiveness: the speed and impact of the spread of false news is not comparable to the length of post factum illumination of truths, as demonstrated by the case of US President Donald Trump (Skewes 2018). 
Within the framework of the project "Jeopardizing Democracy through Disinformation and Conspiracies: Reconsidering Experience of Latvia," the report focuses on the diversity of lies and their moral evaluation. At the same time, the problem of how to weaken and prevent the effects of lies in research is emphasized, supplementing the analysis of individual cases with the challenged of identifying new transformations and functions of lies in a digital democracy. The report analyses two manifestations of lie exposure - lie neutralization and lie normalization. The normalization of lies creates a habit, makes it difficult to neutralize lies. With regard to the normalization of lies, emphasis has been placed, firstly, on a linguistic strategy, in particular the use of euphemisms to conceal the dangerous content of lies, secondly, the repetition of lies, becoming accustomed to distorted truth, and, thirdly, to the concealing of the moral and democratic consequences and effects of lies. In connection with the neutralization of the impact of lies, emphasis is placed, first of all, on the knowledge of lie architecture and communication, in-depth analysis of individual cases, as well as societies media literacy, the general level of intelligence and the role of education.

In analysing the ethics of disinformation, attention is paid to the diversity of lies. The research identifies 34 empirical cases that qualified as false news, including deliberately fabricated content, photograph manipulation, promotional material, propaganda deception, parody, and so on (Tandoc et al. 2018). Alongside the deliberate spread of dangerous lies are ambivalent, permissible, lies; those that provide a short-term pragmatic benefit to the individual ('rescue lies' in health care) or to society (cases where lies reduce panic in the event of a crisis, facilitate police action in criminal investigations, etc.). A multidimensional approach is used to explain the moral aspect of lies, focusing on false content, fraudulent and misleading intentions, especially in party populism and election campaigns, as well as misleading functions and uncritical acceptance and dissemination of false facts within the media.

Keywords: lies, lie diversity, lie verification, lie normalization, lie neutralization

\section{References}

Nǐče, F. (2007). Melošanas māksla. Pārdomas un aforismi. Rīga: Zvaigzne ABC.

Skewes, E. (2018). Time Delays are Not Enough; Media must Call Out Lies. Journal of Media Ethics, 33(2), 97-99. DOI:10.1080/23736992.2018.1435498

Stroud, S. R. (2019). Pragmatist Media Ethics and the Challenges of Fake News. Journal of Media Ethics, 34(4), 178-192. DOI: 10.1080/23736992.2019.1672554

Tandoc, E. C., Lim, Z. W., Ling, R. (2018). Defining "Fake News" A Typology of Scholarly Definitions. Digital Journalism, 6(2), 137-153. DOI: 10.1080/21670811.2017.1360143 


\title{
DEMOKRĀTIJAS KRĪZES UN LATVIJAS RELATĪVĀS ATPALICĪBAS RĀMĒJUMI AKADĒMISKAJĀS UN MEDIJU PUBLIKĀCIJĀS: SISTĒMTRANSFORMĀCIJAS, SABIEDRĪBAS MEDIATIZĀCIJAS UN PUBLISKĀ VIEDOKL̦A ASPEKTI (2018-2021)
}

\author{
Ojārs Skudra \\ \skudrao@gmail.com; ojars.skudra@lu.lv \\ ORCID: https://orcid.org/0000-0002-9742-949X
}

Tēmas aktualitāte saistās ar visās postkomunistiskajās ES dalībvalstīs pēdējā desmitgadē novērojamo demokrātijas sānslīdi (backsliding) jeb dekonsolidāciju, kas daḷai pētnieku jau liek uzskatīt Ungāriju par valsti ar autoritāra tipa politisko režīmu. Šo procesu pirmsākumi meklējami arī sistēmtransformācijas norisēs, it īpaši privatizācijas un politisko partiju sistēmas veidošanās gaitā 20. gadsimta 90. gadu pirmajā pusē. Sistēmtransformācija Latvijā (1985-2004) aptver Latvijas elites - galvenokārt tās ekonomisko un politisko interešu grupu - vadītos politiskos un ekonomiskos, kā arī sociālos un kultūras procesus, kuros norisinājās vietējā autoritārā sociālistiskā režīma nomaiṇa ar "izslēdzošu“ (ekskluzīvu) parlamentāro demokrātiju, tika atjaunota neatkarīga nacionāla Latvijas valsts, un tās ekonomika, veidojoties funkcionējošai tirgus ekonomikai, iekḷāvās kapitālistiskajā pasaules ekonomikā atbilstoši savai veiktspējai starptautiskajā darba dalǐšanā pasaules tirgū. Kopš 20. gadsimta 90. gadu vidus Latvijas politiskās demokrātijas institūcijām parlamentam un valdībai - un īpaši politiskajām partijām ir konstanti negatīvi uzticamības reitingi. Šo problēmu pētniecības un praktiskās risināšanas aktualitāti mūsdienās ietekmē neoliberālās ekonomiskās politikas un globalizācijas problēmas, pasaules kārtības krīze, sabiedrību aptveroša mediatizācija, digitalizācijas paātrināto publiskā viedokḷa fragmentāciju ieskaitot. Ar sistēmtransformācijas ilglaicīgajām sociāli ekonomiskajām un sociāli politiskajām sekām, mediatizācijas procesiem un publiskā viedokḷa fragmentāciju saistītu starpdisciplināru politiskās komunikācijas pētījumu, kas ietvertu demokrātiskā politiskā režīma dekonsolidācijas aspektus, Latvijā ir l̦oti maz. Sistēmmaiṇas un plašākais sistēmtransformācijas laika periods promocijas darbos komunikācijas zinātnē tiek apzīmēts kā "padomju laiks", perestroikas un "Atmodas laiks", "Latvijas trešā atmoda" vai "perestroikas un pēcpadomju periods". Promocijas darbos politikas zinātnē pētīts "populisms Latvijas politisko partiju diskursā”, kā arī "postpadomju polittehnologijas”. Politiskās komunikācijas problemātikai pievērsies tikai politologs Visvaldis Valtenbergs savā 2010. gadā aizstāvētajā promocijas darbā "Interneta politiskās komunikācijas nozīme atklātības un elektroniskās demokrātijas attīstībā”. Politisko līdzdalību un politisko attieksmju attīstību "postkomunistiskajās zemēs" pētījusi sociologe Inta Mieriņa. Pētỉjumi Rietumeiropā un Ziemel̦amerikā liecina, ka politisko ziṇu ieguves avotu pirmajās lomās joprojām ir televīzija un sociālie mediji, kamēr drukātie jeb mantojuma (legacy) mediji - žurnāli un avīzes - spēlē stipri pakārtotu lomu, 
tātad arī politisko zināšanu veidošanās procesā. Latvijas mazskaitlīgo kadru partiju un tāpēc kadru demokrātijas situācijā nozīmīga loma viedokḷu formēšanās un politiskās komunikācijas procesos joprojām ir drukātajiem privātajiem medijiem nedēlas žurnāliem "IR" un "Sestdiena”, kā arī dienas laikrakstiem "Diena” un "Latvijas Avīze". Sistēmtransformācija tajos joprojām tiek raksturota kā nacionālā atbrīvošanās jeb, lietojot politiskās folkloras jēdzienu, kā "Trešā atmoda". Mediatizācijas procesi tiek interpretēti pārsvarā no medijpratỉbas jeb mediju pedagoǵijas pozīcijām, publiskā viedokḷa raksturošanai tiek izmantoti aptauju firmām pasūtītie dati. Demokrātijas krīzes problemātika tiek ignorēta, aizstājot to ar "varas partijas", "rīcībnespèjīgā valdība" un līdzīgiem rāmējumiem, kas ietekmē uzticēšanos demokrātiskajām institūcijām un valdību veidojošajām partijām. Akadēmiska analīze tiek piel̦auta atsevišķ gadījumu komentāros, bet ne politiskās komunikācijas procesu izvērtējumā. Turpmākās izpētes mērḳis būtu noskaidrot, cik mērḳtiecīgi un sistemātiski, drīzāk - haotiski un patvaḷīgi, tiek izmantoti stratēǵiskie rāmējumi un stratēgiskā rāmēšana, lai veicinātu kādu konkrētu politisko mērḳu sasniegšanai vēlamo rezonansi lasītājos un, iespējams, ietekmētu citu mediju dienaskārtību.

Atslēgvārdi: sistēmtransformācija, mediatizācija, publiskais viedoklis, stratēgiskie rāmējumi, politiskā komunikācija, mantojuma mediji

\section{Atsauces}

Cianetti, L., Dawson, J., Hanley, S. (eds). (2020). Rethinking 'Democratic Backsliding' in Central and Eastern Europe. New York: Taylor \& Francis Ltd.

Duvold, K., Berglund, S., Ekman, J. (2020). Political Cultures in the Baltic States. Between National and European Integration. New York: Palgrave Macmillan.

Graney, K. (2019). Russia, the Former Soviet Republics, and Europe since 1989. Transformation and Tragedy. New York: Oxford University Press.

Mierina, I. (2011). Political Participation and Development of Political Attitudes in Post-Communist Countries. PhD Thesis. Riga: University of Latvia. Retrieved from: https://www.szf.lu.lv/petnieciba/promocijas-darbi/

Merkel, W. (2010). Systemtransformation. Eine Einführung in die Theorie und Empirie der Transformationsforschung. 2., überarbeitete und erweiterte Auflage. Wiesbaden: VS Verlag für Sozialwissenschaften.

Skudra, O. (2002). Sistēmtransformācija Latvijā un tās periodizācija. Latvijas Vēsture, 1(45), 37-43.

Valtenbergs, V. (2010). Interneta politiskās komunikācijas nozìme atklätības un elektroniskās demokrātijas attīstībā. Promocijas darbs. Rīga: Latvijas Universitāte. Izgūts no: https://www. szf.lu.lv/petnieciba/promocijas-darbi/ 


\title{
FRAMES OF DEMOCRATIC CRISIS AND THE RELATIVE BACKWARDNESS OF LATVIA IN ACADEMIC AND MEDIA PUBLICATIONS: THE ASPECTS OF SYSTEMIC TRANSFORMATIONS, MEDIATIZATION OF SOCIETY AND PUBLIC OPINION (2018-2021)
}

\author{
Ojārs Skudra \\ \skudrao@gmail.com; ojars.skudra@lu.lv \\ ORCID: https://orcid.org/0000-0002-9742-949X
}

The topicality of the subject relates to the backsliding of democracy has been observed in all post-communist EU Member States over the last decade, where some researchers consider Hungary to be a country with an authoritarian political regime. These processes have their origins in systemic transformations, particularly in privatization and the formation of the political party system in the first half of the 1990s. The system's transformation in Latvia (1985-2004) covers the political and economic processes led by the Latvian elite, mainly its economic and political interest groups, as well as the social and cultural processes that led to the replacement of the local authoritarian socialist regime with an "exclusionary" (exclusive) parliamentary democracy. Additionally, in this process the economy was restored to the capitalist world economy, according to its performance in the international division of work on the world market. Since the mid-1990s, Latvian political democracy institutions, such as the parliament and especially political parties, have consistently negative credibility ratings. The topicality of this research and the practical solving of these problems nowadays is influenced by neoliberal economic policy and globalization problems, including the crisis of the world order, the mediatization surrounding society and the accelerated fragmentation of public opinion spurred on by digitalization. There is very little interdisciplinary political communication research in Latvia related to the long-term socio-economic and socio-political consequences of system transformations, the processes of mediatization and the fragmentation of public opinion, which would include aspects of deconsolidation of the democratic political regime. The period of systemic change and the broadest system transformation periods in communication science's doctoral theses are referred to as the "Soviet time," the period of perestroika and "the time of Awakening," the "Third awakening" or "perestroika and the post-Soviet period." Doctoral theses in political science explore "populism in discourse of Latvian political parties," as well as "post-Soviet political technology." Only political scientist VisvaldisValtenbergs in his dissertation (2010) has addressed the problem of political communication. Political participation and the development of political attitudes in "post-communist lands" has been studied by Inta Mierina. Research in Western Europe and North America showing that television and social media maintain the primary role as political news sources, while printed or heritage (legacy) media - magazines and 
newspapers - play a very subordinate role, therefore so does the process of developing political knowledge. In Latvia, with small-numbered staff parties and therefore in the situation of a staff democracy, such printed private media as the weekly magazines "IR" and "SestDiena," as well as the daily newspapers "Diena" and "Latvijas Avize" are still playing a crucial role in shaping public opinion. The transformation of the system in these sources is still described as a national liberation, or using the concept of political folklore, as "the Third awakening." The mediatization processes are interpreted mainly from media literacy or media pedagogy positions, while data commissioned from survey firms is used to describe public opinions. The issue of the crisis in democracy is being ignored and replaced by such frames as "power parties," "incapacitated government" and the like, which affect trust in democratic institutions and government-forming parties. Academic analysis is allowed in case-by-case comments, but not in the evaluation of political communication processes. Further research would aim to find out how targeted and systematic, or rather, strategic frames and strategic framing is used in a chaotic and arbitrary way to promote the desired resonance among the audiences of readers, to achieve specific political objectives and to possibly influence the agendas of other media.

Keywords: system-transformation, mediatization, public opinion, strategic frames, political communication, legacy media

\section{References}

Cianetti, L., Dawson, J., Hanley, S. (eds). (2020). Rethinking 'Democratic Backsliding' in Central and Eastern Europe. New York: Taylor \& Francis Ltd.

Duvold, K., Berglund, S., Ekman, J. (2020). Political Cultures in the Baltic States. Between National and European Integration. New York: Palgrave Macmillan.

Graney, K. (2019). Russia, the Former Soviet Republics, and Europe since 1989. Transformation and Tragedy. New York: Oxford University Press.

Mierina, I. (2011). Political Participation and Development of Political Attitudes in Post-Communist Countries. PhD Thesis. Riga: University of Latvia. Retrieved from: https://www.szf.lu.lv/petnieciba/promocijas-darbi/

Merkel, W. (2010). Systemtransformation. Eine Einführung in die Theorie und Empirie der Transformationsforschung. 2., überarbeitete und erweiterte Auflage. Wiesbaden: VS Verlag für Sozialwissenschaften.

Skudra, O. (2002). Sistēmtransformācija Latvijā un tās periodizācija. Latvijas Vēsture, 1(45), 37-43.

Valtenbergs, V. (2010). Interneta politiskās komunikācijas nozìme atklätības un elektroniskās demokrātijas attīstībā. Promocijas darbs. Rīga: Latvijas Universitāte. Izgūts no: https://www. szf.lu.lv/petnieciba/promocijas-darbi/ 


\title{
SUN̦U BARĪBAS RAŽOTĀJA PUBLISKĀ RETORIKA AR BARĪBU SAISTĪTAJĀ MEGAESOPHAGUS UZLIESMOJUMĀ SUN̦IEM: LATVIJAS GADĪJUMS (2015-2016)
}

\author{
Ilze Matīse-VanHoutana \\ $\triangle$ imatise.vh@gmail.com \\ ORCID: https://orcid.org/0000-0003-3243-6741

\section{Lilija Geine-Romanova} \\ $\triangle$ lilija_romanova@inbox.lv \\ ORCID: https://orcid.org/0000-0003-2978-0437
}

Pēdējos 50 gados pasaulē strauji pieaug cilvēku un līdz ar to lauksaimniecības un mīḷzīvnieku skaits, kas vienlaikus palielina pieprasījumu pēc kvalitatīvas un nekaitīgas pārtikas un dzīvnieku barības. Lai apmierinātu šo pieprasījumu, ne tikai jāpalielina pārtikas un barības ražošanas jaudas, bet arī jāveic pasākumi, kuru mērķis ir garantēt, lai pārtika un barība, kas nav nekaitīga, netiktu laista tirgū. Svarīgi ir nodrošināt, ka pastāv sistēma ar pārtikas nekaitīgumu saistītu problēmu identificēšanai un to risināšanai, tādējādi radot priekšnoteikumus iekšējā tirgus pareizai darbībai un cilvēku un dzīvnieku veselības aizsardzībai. Vairākas viena otrai sekojošas pārtikas un barības krīzes ir pierādījušas, ka neveiksme jebkurā pārtikas un barības aprites posmā var izraisīt nozīmīgas sekas sabiedrības veselībā un ekonomikā. Par pārtikas un barības nekaitīgumu joprojām sākotnēji atbild pārtikas un barības nozares komersanti. Pārtikas drošībai ir jābūt svarīgākajai komersanta prioritātei. Gadījumi, kad konstatēta pārtikas un barības neatbilstība nekaitīguma prasībām, gūst plašu rezonansi medijos un sabiedrībā, bieži pārtopot pat skandālos, rada lielus ekonomiskus zaudējumus, maina patērētāju paradumus un reizēm atstāj dažāda smaguma sekas uz cilvēku vai dzīvnieku veselību. Nereti ar šādiem skandāliem negodīgi komersanti cenšas ietekmēt tirgu savā labā, izspēelējot negodīgas konkurences kārti un izliekoties, ka pret viņiem celtie iebildumi ir izdomājums un ka to dara konkurenti, kuri vēlas ieriebt komersantam. Zaudētājs diemžēl ir sabiedrība, kurai ir grūti saprast, kam ticēt un uzticēties. Šā apskata mērḳis ir apkopot un izanalizēt pieejamo informāciju ar suṇu barību saistītajā megaesophagus/polineiropātijas (ME/PNP) uzliesmojumā suṇiem Latvijā 2015.-2016. gadā un izdarīt secinājumus par dezinformācijas ietekmi uz sabiedrības viedokḷa veidošanu. Analizējot neatkarīgas pētnieku grupas iegūtos pierādỉjumus katrā pētījuma posmā un barības ražotāja rīcību un komentārus katrā šā gadījuma posmā, novērtēta sabiedrības (patērētāju) attieksme pret šo barības krīzi, ražotāju, tiesvedības iznākumu un zinātniekiem kopumā. 2015. gada pavasarī Latvijas veterinārārsti ziṇoja par neparasti lielu ME/PNP gadījumu skaitu, un tika sākti vairāki pētījumi, lai apturētu šo uzliesmojumu, izpētītu slimību un veiktu gadỉjumu monitoringu. Pētījumu gaitā atklāts, ka ME/PNP uzliesmojuma galvenais riska faktors ir konkrēta suṇu barības ražotāja produkcijas izēdināšana mājdzīvniekiem. Par to tika ziṇots ražotājam, 
valsts institūcijām un informēta sabiedrība. Taču barības ražotājs šādus apgalvojumus nosauca par muļ̣̣ībām, noliedza saslimšanas gadỉjumu esamỉbu, apvainoja pētniekus datu falsifikācijā un sāka tiesvedības procesus pret pētniekiem un cietušo sunu īpašniekiem. Sabiedrība aktīvi akceptēja ražotāja viedokli un uztvēra šo skandālu kā konkurences cinnu pret vietējo ražotāju. 2016. gada otrajā pusē, noslēdzoties visiem pētījuma posmiem, tika iegūti pierādījumi, ka konkrētā sunu barība ir cieši saistīta ar ME/PNP uzliesmojumu, bet ražotājs turpināja apgalvot, ka šĩ ir organizēta l̦aunprātīga nomelnošanas kampaņa ar mērḳi radīt kaitējumu l̦oti veiksmīgam, stabilam uzṇēmumam, tādējādi atbrīvojot vietu importa produktam. Sabiedrības viedoklis sašḳēlās, un liela daḷa uzskatîja, ka ražotājs tiek apmelots. Valsts institūcijas nerīkojās izlēmīgi, atstājot komunikāciju starp komersantu un pētniekiem viṇu pašu ziņā. Pārtraucot suṇiem izēdināt šo barību, ME/PNP uzliesmojums beidzās, un slimības gadījumu skaits atgriezās iepriekšèjā līmenī. Noslēdzoties tiesvedības procesam, kurā atzīts, ka pētnieki rīkojušies atbildīgi, godprātīgi pildot savus pienākumus, dạa sabiedrības bija pārliecināta par pētỉjumu patiesumu, bet daḷas sabiedrības viedoklis joprojām svērās par labu suṇu barības ražotājam. Tādējādi, noniecinot zinātniskos sasniegumus un pētījumu rezultātus, izplatot dezinformāciju, ražotājam izdevās pārliecināt dal̦u sabiedrības noliegt neapgāžamus pētijumos iegūtus faktus, graujot sabiedrības uzticību zinātnei un veterinārārstu profesionalitātei, un šo viedokli neizdevās mainīt pat tiesas lēmumiem par labu pētnieku grupas dalībniekiem un dzīvnieku īpašniekiem. Šis gadījums uzskatāmi atspoguḷo, ka kampaņveidīgi izveidotais sabiedrības viedoklis ar sazvērestības teoriju palīdzību ir noturīgs un to ir ārkārtīgi grūti mainīt, pat ar neapstrīdamiem pierādījumiem. Turklāt tas pierāda, ka sazvērestības teoriju popularitāte sabiedrībā var radīt ilgstošu sabiedrības veselības apdraudējumu, kura dēl veselïbu un dzīvību zaudēt var gan cilvēki, gan dzīvnieki.

Atslēgvārdi: dezinformācija, suṇu barība, pārtikas nekaitīgums, pārtikas skandāls, megaesophagus

\section{Atsauces}

ES (2002). Eiropas Parlamenta un Padomes Regula (EK) Nr. 178/2002 (2002, 28. janvāris), ar ko paredz pārtikas aprites tiesību aktu vispārīgus principus un prasības, izveido Eiropas Pārtikas nekaitīguma iestādi un paredz procedūras saistībā ar pārtikas nekaitīgumu. Izgūts no: https://eur-lex.europa.eu/eli/reg/2002/178/oj/?locale=LV

Hurley, K. J. DVM et al. (2021). A Comparative Analysis of Two Unrelated Outbreaks in Latvia and Australia of Acquired Idiopathic Megaesophagus in Dogs Fed Two Brands of Commercial Dry Dog Foods: 398 Cases (2014-2018). Journal of the American Veterinary Medical Association, 259(2), 172-183. DOI: doi.org/10.2460/javma.259.2.172

Saeima (2008). Dzīvnieku barības aprites likums. Latvijas Vēstnesis, Nr. 177, 13. nov.; Latvijas Republikas Saeimas un Ministru Kabineta Ziņotājs, Nr. 24, 23. dec. Izgūts no: https://likumi.lv/ ta/id/183720-dzivnieku-baribas-aprites-likums 


\title{
PUBLIC RHETORIC OF A DOG FOOD \\ MANUFACTURER IN A FOOD-RELATED \\ MEGAESOPHAGUS OUTBREAK IN DOGS: \\ OUTBREAK IN LATVIA (2015-2016)
}

\author{
Ilze Matīse-Van Houtana \\ $\bigotimes$ imatise.vh@gmail.com \\ ORCID: https://orcid.org/0000-0003-3243-6741 \\ Lilija Geine-Romanova \\ $\triangle$ lilija_romanova@inbox.lv \\ ORCID: https://orcid.org/0000-0003-2978-0437
}

In the last 50 years the world's population has increased and, proportionally, farm and companion animal populations have increased as well, leading to an expanded need for high quality and safe foods for people and safe feed for animals. To satisfy these demands, it is necessary to increase food and feed production capacity as well as to adopt measures aimed at guaranteeing that unsafe food is not placed on the market; to ensure that systems exist to identify and respond to food safety problems so as to ensure the proper functioning of the internal market and the protection of human and animal health. Several consecutive feed and food crises have shown that failures at any stage in the feed and food chain can have important economic consequences and an impact on human health. Primary responsibility for feed and food safety rests with the relevant business operator and it must be an important priority for them. Cases when feed and food doesn't meet safety requirements often provoke a reaction in the public media, spreading dissatisfaction and outrage widely in social media, often reaching the status of a scandal concurrently leading to economic losses, changes in consumers habits, and in some cases leaving variably severe impact on the health of animals and humans. Often, in these scandals, dishonest food and feed operators try to influence the market to suit their own interests by playing the card of "unfair competition" and pretending that objections raised against them are unsubstantiated, that they are fabricated by their competitors who want to harm their business. Unfortunately, the major loser in such cases is society, which cannot understand who is telling the truth and whose message can be trusted. The goal of this review is to collect and analyse available information about commercial-dogfood-associated outbreaks of megaesophagus/polyneuropathy (ME/PNP) in dogs in Latvia from 2015-2016 and determine what was the impact of disinformation on public opinion. Analyzing the evidence obtained by an independent team of researchers at each stage of the study and the food manufacturer's actions and comments at each stage of the outbreak, the public's (consumers') attitude to the food crisis, the manufacturer, the outcome of the court proceedings and the scientists were assessed. In the spring of 2015, Latvian veterinarians reported an unusually high number of ME/PNP cases, and several studies were launched to investigate the disease, stop the outbreak, and monitor existing cases. The research revealed that 
the main risk factor for the ME/PNP outbreak was the use of a particular brand dog food produced locally in Latvia. These findings were reported to the manufacturer, public authorities and the public in general. However, the food manufacturer responded by calling these allegations nonsense, by denying the existence of the disease, by accusing the researchers of falsifying the data and by initiating legal proceedings against the researchers and the owners of the sick dogs. The public was receptive to the viewpoint of the food manufacturer and perceived this scandal as a competition against the domestic producer. At the end of all the phases of study, in the second half of 2016, evidence was found that the dog food in question was closely linked to the ME/PNP outbreak, but the manufacturer continued to claim that this was an abusive defamation campaign aimed at harming a very successful, stable, company. Public opinion was divided, but a large portion of society believed that the producer was being slandered. State institutions did not act decisively, leaving communication between the merchant and the researchers. With the cessation of feeding this food, the ME/PNP outbreak ended and the number of cases returned to previous levels. At the end of litigation, which found that the researchers and veterinarians had acted responsibly in carrying out their professional duty in good faith, a part of the public was convinced about the research results, while another part of the public still weighed in favor of the dog food manufacturer. Thus, by disparaging scientific advances and research results, disseminating disinformation, the manufacturer managed to persuade part of the public to deny irrefutable research findings, undermining public confidence in science and veterinary professionalism, and even the rulings of the Court of Latvia in favor of the researchers and animal owners. This case demonstrates that the spread of campaign-based conspiracy theories in the public is persistent and extremely difficult to change, even with conclusive evidence. Moreover, it can lead to a protracted public health hazard, resulting in the loss of health and loss of life in humans and animals.

Keywords: disinformation, dog food, food safety, food scandal, megaesophagus

\section{References}

EU (2002). Regulation (EC) No 178/2002 of the European Parliament and of the Council of 28 January 2002 laying down the general principles and requirements of food law, establishing the European Food Safety Authority and laying down procedures in matters of food safety. Retrieved from: https://eur-lex.europa.eu/legal-content/EN/ALL/?uri=celex\%3A32002R0178

Hurley, K. J. DVM et al.(2021). A Comparative Analysis of Two Unrelated Outbreaks in Latvia and Australia of Acquired Idiopathic Megaesophagus in Dogs Fed Two Brands of Commercial Dry Dog Foods: 398 Cases (2014-2018). Journal of the American Veterinary Medical Association, 259(2), 172-183. DOI: doi.org/10.2460/javma.259.2.172

Saeima (2008). Law on Circulation of Animal Feedingstuffs. Latvijas Vēstnesis, No. 177, Nov. 13; Latvijas Republikas Saeimas un Ministru Kabineta Ziņotājs, No. 24, Dec. 23. Retrieved from: https://likumi.lv/ta/en/en/id/183720 


\title{
SUNU BARĪBAS RAŽOTĀJA PUBLISKĀ RETORIKA AR BARĪBU SAISTĪTAJĀ MEGAESOPHAGUS UZLIESMOJUMĀ SUN̦IEM: AUSTRĀLIJAS GADĪJUMS (2017-2018)
}

\author{
Ilze Matīse-VanHoutana \\ \imatise.vh@gmail.com \\ ORCID: https://orcid.org/0000-0003-3243-6741 \\ Lilija Geine-Romanova \\ $\bigotimes$ lilija_romanova@inbox.lv \\ ORCID: https://orcid.org/0000-0003-2978-0437
}

Slimības uzliesmojumi, kas saistīti ar pārtiku un skar nozīmīgu sabiedrības dalı, ir auglīga augsne viltus ziṇām un sazvēestības teorijām. Šādu slimību uzliesmojumu izpēte un rezultātu izskaidrošana sabiedrībai var būt komplicēta, jo īpaši tad, kad konkrētu cēloni jeb ierosinātāju (toksīnu, infekciozu ierosinātāju) neizdodas atrast, bet saikni ar barību apliecina epidemiologiskās analīzes dati. Sabiedrība un pastarpināti arì par sabiedrības un dzīvnieku veselību atbildīgās iestādes ir ieinteresētas, lai uzliesmojums maksimāli ātri tiktu likvidēts. To ir iespējams izdarīt tikai tad, ja operatīvi tiek atrasts cēlonis un apturēta kaitīgā faktora izplatîba. Tomēr produktu atsaukšana un to izplatības ierobežošana ir saistìta ar nozīmīgiem ekonomiskiem zaudējumiem, tāpēc, uzliesmojot ar pārtiku saistìtai slimībai, vērojama ekonomisko, politisko un sabiedrības veselības interešu sadursme. Šie procesi ir līdzīgi norisēm, kas vērojamas patlaban, kad Covid-19 izplatība pieprasa ierobežojumus biznesam, it îpaši tūrismam un restorāniem. Ar komerciālo barību saistītā megaesophagus (barības vada dilatācija) uzliesmojuma izpēte suṇiem Austrālijā ḷauj analizēt ražotāja publisko retoriku un salīdzināt to ar ietekmi uz kopējo uzliesmojuma apjomu, suṇu īpašnieku reakciju un politiķu rīcību. Šo datu pretnostādne ar līdzīgas izcelsmes slimības analīzi Latvijā ḷauj izdarìt secinājumus par ražotāja un sabiedrisko organizāciju tiražēto sazvērestības teoriju ietekmi uz sabiedrības veselību. Austrālijas suṇu megaesophagus uzliesmojums bija saistìts ar kompānijas Mars meitas kompānijas Mars Petcare Australia ražoto barību Advance Dermocare, kas tika ražota izplatī̌šanai Austrālijā un Jaunzēlandē. To atklāja epidemioloğiskā izpēte, ko veica Melburnas Universitāte, un šie dati kḷuva zināmi plašākai sabiedrībai 2018. gada decembrī. Pirmie signāli par iespējamo slimības saikni ar barību tika saņemti 2017. gada novembrī un decembrī, kad megaesophagus tika diagnosticēta sešiem no 60 Viktorijas policijas suṇiem un vienīgais vienojošais faktors bija tiem dotā barība - Advance Dermocare. Tika veikta vietēja mēroga izmeklēšana, kurā iesaistijās Melburnas Universitāte un Mars veterinārie speciālisti, taču netika informēta ne sabiedrība, ne PetFAST platforma (organizācija, kurai veterinārārsti ziņo par mājdzīvnieku slimību incidentiem, kas varētu būt saistìti ar barību). Neviena sākotnējā izpēte barībā neatrada novirzes, kas izskaidrotu slimības rašanos. 2018. gada martā vienlaikus tika atklāti vēl daži megaesophagus gadỉjumi suṇiem, 
kas baroti ar Advance Dermocare, kā arī presē parādijāas apraksts par reto slimību - megaesophagus, kas skārusi policijas suṇus. 2018. gada 23. martā Mars Petcare Australia publicēja Advance Dermocare atsaukumu, pamatojot to kā soli drošības dẹl (precautionary), bet apliecinot, ka barībā nav atklātas novirzes, kas izskaidrotu slimības rašanos. Kompānija izplatija paziņojumu gan medijos, gan internetā un aicināja pārstāt barot sunus ar Advance Dermocare un to atdot atpakal ražotājam. Paziņojumā patērētājus aicināja vērsties pie kompānijas, lai iegūtu kompensāciju, un ziņot par megaesophagus gadijumiem Mars, Melburnas Universitātei vai PetFAST. No 2018. gada aprị̄la līdz jūnijam uzliesmojumā identificèto gadījumu skaits turpināja pieaugt, sasniedzot vairāk nekā 145 suṇus. Suṇu ìpašnieki bija neapmierināti ar Mars Petcare Australia lēno rīcību un pieprasīja veikt Senāta izmeklēšanu. Tā notika no 2018. gada jūnija līdz augustam. Suņu īpašnieki pieprasija, ka ir nepieciešams stingrāks barības regulējums, neatḷaujot ražotāja pašregulāciju, kas bija spēkā līdz tam. Viṇi uzstāja arī, ka saskaṇā ar atbildīgu rīcỉbu un rūpēm par dzīvniekiem Mars Petcare Australia bija publiski jāziņo par potenciālo saikni starp barību un slimību jau 2017. gada decembrī. 2018. gada decembrī noslēdzās Melburnas Universitātes vadītais epidemiologisks case-control pētỉjums, kurā tika noskaidrots, ka saslimšanas risks suniem, kas baroti ar Advance Dermocare, bija 437 reizes lielāks nekā suņiem, kas baroti ar citu barību (odds ratio, OR; vērtība, kas lielāka par 20, norāda uz ḷoti ciešu sakarību). Tikai pēc šā rezultāta parādīšanās presē Mars Petcare Australia atzina, ka viṇu produktā patiešām ir kaut kas vēl neatklāts, kas izraisijis suṇu saslimšanu. Kompānija apsolijja turpināt izmeklēšanu un veidoja ekspertu grupu, kas izvērtēja visus līdz šim iegūtos datus, lai izdarītu secinājumus par iespējamiem saslimšanas cēloṇiem, turpmākajiem pètījumiem un rīcību nākotnē, ja šādi uzliesmojumi atkārtotos. Kopumā Mars Petcare Australia retorika uzliesmojuma gadījumā vērtējama kā uzmanīga, neuzkrītoša un samērā nogaidoša, tomēr atbildīga: kompānija sāka brīvprātīgu produkta atsaukšanu, aktīvi iesaistijās izmeklēšanas procesā, rūpējās par kompensācijām slimības skarto sunu saimniekiem un sekmēja izpētes procesu, lai novērstu lídzīgu incidentu rašanos nākotnē. Mars rīcība bija diametrāli pretēji ražotāja rīcībai Latvijā, kad ražotājs (“Tukuma Straume”) izplatỉja apzināti nepatiesas ziņas gan par slimību, gan tās izmeklēšanu, nebrīdināja suṇu saimniekus un brīvprātīgi neatsauca produktu. Austrālijas uzliesmojums bija īslaicīgs (5-6 mēneši) un beidzās pēc produkta atsaukuma, savukārt Latvijā slimības uzliesmojums ilga vairākus gadus un beidzās tikai tad, kad kritās produkta pārdošanas apjoms un izmainījās pats produkts. Pētijjumu rezultāti Austrālijā un Latvijā bija identiski - epidemiologiski apstiprināta cieša saikne starp barību un slimību, bet netika atrasts konkrēts cēlonis vai faktoru kopums barībā. Austrālijas uzliesmojumā ražotājs kooperējās un sadarbojās ar univeristātes pētniekiem, bet Latvijā ražotājs izplatīja sazvērestības teoriju, apvainoja veterinārārstus par datu safabricēšanu un sabiedrības informēšanu un sāka tiesvedību pret veterinārārstiem. To sekmēja politiskā aizmugure, ko nodrošināja Zemkopības ministrija un Lauksaimniecības organizāciju sadarbības padome. Tādējādi nekompetenta ražotāja rīcỉba, ko akceptē un piesedz pie varas esoši politiķi, kopā ar iespēju uzpirkt medijus, var ilgstoši apdraudēt (mājdzìvnieku un/vai viņu saimnieku) veselību. Slimības uzliesmojuma apturēšana Austrālijā bija efektīvāka, 
jo informācijas apmain̦a starp Mars un veterinārārstiem bija profesionāla un pēc būtības, tādējādi neradot augsni sazvērestības teorijām un dezinformācijai.

Atslēgvārdi: sazvērestības teorijas, sabiedrības veselība, slimības uzliesmojums, publiskā retorika, megaesophagus

\section{Atsauces}

Hurley, K. J. DVM et al. (2021). A Comparative Analysis of Two Unrelated Outbreaks in Latvia and Australia of Acquired Idiopathic Megaesophagus in Dogs Fed Two Brands of Commercial Dry Dog Foods: 398 Cases (2014-2018). Journal of the American Veterinary Medical Association, 259(2), 172-183. DOI: doi.org/10.2460/javma.259.2.172 


\title{
PUBLIC RHETORIC OF A DOG FOOD \\ MANUFACTURER IN A FOOD-RELATED \\ OUTBREAK OF MEGAESOPHAGUS IN DOGS: \\ OUTBREAK IN AUSTRALIA (2017-2018)
}

\author{
Ilze Matīse-Van Houtana \\ $\bigotimes$ imatise.vh@gmail.com \\ ORCID: https://orcid.org/0000-0003-3243-6741 \\ Lilija Geine-Romanova \\ $\triangle$ lilija_romanova@inbox.lv \\ ORCID: https://orcid.org/0000-0003-2978-0437
}

Food-related outbreaks affecting a significant portion of society are fertile ground for false news and conspiracy theories. Investigating outbreaks of such diseases and explaining the results to the public can be complicated, especially when a specific cause or agent (toxins, infectious agents) cannot be found, but the link with food is confirmed by epidemiological analysis. It is in the interest of the public and, indirectly, of the authorities responsible for public and animal health, that the outbreak is eradicated as soon as possible, which can only be done if the cause is found promptly and the spread of the harmful factor is stopped. However, product recalls and restrictions on distribution involve significant economic losses, leading to a conflict of economic, political and public-health interests in a food-related outbreak (such conflicts of intereses can also be seen in the Covid-19 restrictions on various businesses, especially tourism and restaurants). Research on a foodrelated megaesophagus (esophageal dilatation) outbreak in dogs in Australia allows the manufacturer's public rhetoric to be analyzed and compared with the impact on the overall outbreak, the reaction of dog owners and the actions of politicians. Contrasting this data with the analysis of a disease of similar origin in Latvia allows conclusions to be drawn about the public health impact of conspiracy theories circulated by the producer and public organizations. The outbreak of Australian canine megaesophagus was linked to Advance Dermocare, a food produced by Mars Petcare Australia, a subsidiary of Mars, which was produced for distribution in Australia and New Zealand. This was demonstrated by an epidemiological study carried out by the University of Melbourne, which became available to the general public in December 2018. The first indications of a possible link between the disease and food were received in November-December 2017, when megaesophagus was diagnosed in 6/60 Victorian police dogs and the only unifying factor was the food fed to them - Advance Dermocare. A local investigation involving the University of Melbourne and Mars veterinarians was carried out, but neither the public nor the PetFAST platform (an organization to which veterinarians report incidents of pet diseases that may be related to feed) was informed. None of the initial studies found abnormalities in the feed that would explain the onset of the disease. At the same time, in March 2018, a few more cases of megaesophagus were discovered in 
dogs fed with Advance Dermocare, and a description of a rare disease, megaesophagus, which affected police dogs, appeared in the press. On March 23, 2018, Mars Petcare Australia published a voluntary recall of Advance Dermocare justifying it as a precautionary step, but confirming that no anomalies have been identified in the food to date that could explain the onset of the disease. The company issued a statement both in the media and on the Internet calling for the public to stop using the feed and for them to return Advance Dermocare. The public was to contact the company for compensation and report any cases of megaesophagus to Mars, the University of Melbourne or PetFAST. In April-June 2018, the number of cases identified in the outbreak continued to grow, reaching $>145$ dogs. In response, dog owners were dissatisfied with the hitherto slow action of Mars Petcare Australia and demanded a Senate inquiry, which was held from June to August 2018. Dog owners insisted on the need for stricter food regulations, not satisfied with the exisiting policy of self-regulation by the manufacturer. They also contended that, in line with responsible animal welfare and care, Mars Petcare Australia should have publicly announce the potential link between food and disease as early as December 2017. An epidemiological case-control study led by the University of Melbourne was completed in December 2018, which found that dogs fed Advance Dermocare had a 437 times higher risk of developing the disease than dogs fed other diets (odds ratio, OR; a value $>20$ indictes very tight relationship). Yet, it was only after this result appeared in the press that Mars Petcare Australia acknowledged that there was indeed something undiscovered in their product that had caused the dogs to become ill. Thereafter, the company promised to continue the investigation and set up a team of experts who would evaluate all the data obtained so far and conclude on possible causes, as well as further research and future action in the event of a recurrence of such outbreaks. In general, the rhetoric of Mars Petcare Australia in the event of an outbreak can be described as careful, inconspicuous and relatively wait-and-see but overall responsible: the company initiated a voluntary recall, actively participated in the investigation, compensated the owners of the affected dogs and facilitated an investigation process to prevent similar incidents in the future. The actions of Mars were diametrically opposed to the actions of the producer in Latvia, as the producer (Tukuma Straume) deliberately spread false information about both the disease and its investigation, did not warn the dog owners and did not voluntarily recall its product. As a result, the Australian outbreak was shortlived (5-6 months) and ended after the product was recalled, while the Latvian outbreak lasted for several years and ended only when sales of the product fell and the product was changed. The results of the studies in Australia and Latvia were identical - an epidemiologically confirmed close link was established between the feed and disease, but no specific cause or set of factors was found in that feed. In the Australian outbreak, the producer cooperated and collaborated with investigators at the university, but in Latvia the producer spread a conspiracy theory, accused veterinarians of fabricating data and spreading it among the public, and initiated legal proceedings against veterinarians. Moreover, such actions were facilitated by the political backing provided by the Ministry of Agriculture and the Cooperation Council of Agricultural Organizations. Thus, the politically backed actions of an 
incompetent producer, coupled with the possibility of co-opting the media, can result in long-term health risks for pets and/or their owners. Halting the outbreak in Australia was more effective because the exchange of information between Mars and veterinarians was professional and substantive. This case, unlike in Latvia, did not create fertile grounds for conspiracy theories and disinformation.

Keywords: conspiracy theories, public health, disease outbreak, public rhetoric, megaesophagus

\section{References}

Hurley, K. J. DVM et al. (2021). A Comparative Analysis of Two Unrelated Outbreaks in Latvia and Australia of Acquired Idiopathic Megaesophagus in Dogs Fed Two Brands of Commercial Dry Dog Foods: 398 Cases (2014-2018). Journal of the American Veterinary Medical Association, 259(2), 172-183. DOI: doi.org/10.2460/javma.259.2.172 


\title{
SAZVĒRESTĪBAS TEORIJU \\ LOKALIZĀCIJAS PIEMĒRI SOCIĀLĀS TĪKLOŠANĀS VIETNĒ FACEBOOK
}

\author{
Mārtiņš Pričins \\ $\bigotimes$ martins.pricins@lu.lv \\ ORCID: https://orcid.org/0000-0003-1307-4810
}

Neskaidrību un satraukuma laikā sabiedrībā pieaug nepieciešamība pēc kvalitatīvas un uzticamas informācijas. Koronavīrusa infekcija un ar to saistītā ietekme uz iedzīvotāju ikdienu kḷuva par nopietnu pārbaudījumu visdažādākajos aspektos, īpaši informatīvajā vidē sociālajos medijos, kur sāka strauji izplatīties dažādu veidu maldinoša un nepārbaudīta informācija. Akadēmiskajā literatūrā izšķir maldinošu informāciju, kas izveidota un izplatīta bez manipulativiem vai l̦aunprātīgiem nodomiem, un dezinformāciju, kas ir apzināti (bieži organizēti) mēgénājumi manipulēt ar informāciju ekonomisku vai politisku iemeslu dẹl vai vienkārši izjaucot publiskās komunikācijas procesus (UNESCO 2018). Klasificējot nepatiesas informācijas sniegšanas veidus, tikai daži autori izšķir sazvērestības teorijas kā svarīgu jēdzienu un atsevišķu informatīvā lauka fenomenu (Kapantai et al. 2020). Sazvērestības teorijas ir definējamas kā stāsti bez faktu bāzes, jo tām nav patiesībai noteiktā pamata. Tajās parasti svarīgie notikumi tiek skaidroti ar valdību vai ietekmīgu indivīdu slepenu sazvērestību (Zannettou et al. 2018). Sazvērestības teorijām ir četri raksturojoši lielumi: eksistē grupa, kas darbojas slepenībā, lai ietekmētu institūcijas, uzurpētu varu, slēptu patiesību vai gūtu labumu uz kopīgā labuma rēķina. Tādējādi var noteikt formulu, pēc kuras veidojas sazvērestības teorijas galvenie elementi: iesaistītie dalībnieki + konkrētie apstākḷi + motivācija + cietēji (Uscinski, Parent 2014). Sazvērestības teorijām pēc noklusējuma ir grūti pārbaudīt patiesumu vairāku iemeslu dēḷ. Pirmkārt, visbiežāk tām trūkst pierādījumu bāzes; otrkārt, tās izplata indivīdi, kas paši tic to patiesumam; treškārt, pierādijjumi, kas atspēko sazvērestību, tiek uzskatīti par vēl vienu sazvērestības pierādījumu (EAVI 2018). Tēmu ir vērts pētīt tāpēc, ka Latvijā pastāv apstākḷi, kas var likt sabiedrībai sliekties ticēt sazvērestības teorijām. Viens no iemesliem ir zemais uzticēšanās līmenis galvenajām valsts institūcijām: Latvijas Republikas Saeimai (19\%), valdībai (23\%), politiskajām partijām (7\%), valsts pārvaldei (27\%), amatpersonām (27\%) (Eirobarometrs 2021; SKDS 2021). Tāpat fiksēts neuzticēšanās pieaugums Latvijas pamatstraumes medijiem - no 36\% 2020. gadā līdz 48\% 2021. gadā -, kas ir raksturīga tendence Baltijas un Austrumeiropas valstīm (Hajdu et al. 2021). Domnīcas Providus 2021. gadā veiktā aptauja liecina, ka vērojama saistība starp uzticēšanos citiem cilvēkiem un uzticēšanos Latvijas institūcijām - indivīdi, kas neuzticas citiem, biežāk neuzticas arī institūcijām. Salīdzinot ar pārējām grupām, īpaši zems uzticēšanās līmenis ir cilvēkiem ar pamatizglīî̉bu (apmēram 22\%). Ziņojuma mērḳis ir noskaidrot, kādas ir sazvērestības teoriju praktiskās izpausmes sociālās tīklošanās vietnē Facebook latviešu valodas saturā. Ar analīzes rīka CrowdTangle palīdzību ziņojuma vajadzībām tika identificēti portālu Delfi.lv un LSM.lv Facebook populārākie ieraksti, kas 
skar Covid-19 tēmu 2021. gada janvārī, tālāk analizējot populārākos komentārus, kas guva lielāko reakciju skaitu. Identificētas trīs ar šo tēmu saistītas galvenās komentāru grupas, kurās novērotas sazvērestības teoriju pazīmes: koronavīrusa testu veikšana, vara un bagātība. Testu veikšanas grupā komentāros tika apgalvots, ka testiem neuzticas, dati par inficēto skaitu ir falsificēti un diennaktī nav iespējams pārbaudìt tik lielu cilvēku skaitu. Komentāru grupā par varu ir fiksētas atsauces uz ārējiem spēkiem, kas kontrolē situāciju pasaulē vai valstī, un ka no šìs varas tik drīz neatbrīvosies. Ar bagātību saistītajos komentāros ir norādes uz nepieciešamību "turēt tautu nabadzībā, lai vieglāk manipulētu". Analīzes rezultāti liecina, ka Facebook sazvērestību ierakstu autori savās lapās reti veido savus lokalizācijas piemērus, to dara pārsvarā lietotāji, komentējot mediju ierakstus sociālajā tīklošanās vietnē Facebook. Komentāros vietējās ziṇas, ko publicē mediji, tiek interpretētas kontekstā ar tobrīd izplatītām sazvērestības teorijām. Ierakstos paustajām sazvērestības teorijām ir vērojamas savstarpējās pretrunas interpretācijās un faktos, kas nereti ir paskaidroti rakstos, kā arī zināšanu trūkumā. Atsevišḳos gadījumos sazvērestības teorijas tiek pamatotas ar Latvijas amatpersonu straujo rīcības maiṇu vai lēmumu nekonsekvenci, kas kḷuva par pamatu to lokalizēšanai.

Atslēgvārdi: sazvērestības teorijas, nepatiesa informācija, sociālie mediji, politiskā komunikācija

\section{Atsauces}

EAVI (2018). Infographic: Beyond Fake News - 10 Types of Misleading News - Seventeen Languages. www.eavi.eu. Retrieved from: https://eavi.eu/beyond-fake-news-10-types-misleading-info/

Eirobarometrs (2021). Standarta Eirobarometrs 94. Sabiedriskā doma Eiropas Savienībā. Nacionālais ziņojums. Rīga: Kantar. Izgūts no https://lvportals.lv/wwwraksti/TEMAS/FAILI/ EIROBAROMETRS_SAB_DOMA_ZIEMA_2020_2021_NACIONALAIS_ZINOJUMS_ LATVIJA.PDF

Hajdu, D., Klingová, K., Milo, D., Sawiris, M. (2021). GLOBSEC Trends 2021. Bratislava: GLOBSEC. Retrieved from: https://www.globsec.org/wp-content/uploads/2021/06/GLOBSEC-Trends2021_final.pdf

Kapantai, E., Christopoulou, A., Berberidis, C., Peristeras, V. (2020). A Systematic Literature Review on Disinformation: Toward a Unified Taxonomical Framework. New Media \& Society, 23(5), 1301-1326. DOI: 10.1177/1461444820959296

SKDS (2021). Latvijas barometrs. Latvijas iedzīvotāju noskaņojuma vērtējums. Izgūts no: https:// www.skds.lv/docs/1414/Latvijas_barometrs_022021.pdf

UNESCO (2018). Journalism, 'Fake News' \& Disinformation. Paris: UNESCO Series on Journalism Education. Retrieved from: https://en.unesco.org/fightfakenews

Uscinski, J. E., Parent, J. M. (2014). Conspiracy Theories in America. Oxford: Oxford University Press.

Zannettou, S., Sirivianos, M., Blackburt, J., Kourtellis, N. (2019). The Web of False Information: Rumors, Fake News, Hoaxes, Clickbait, and Various Other Shenanigans. Journal of Data and Information Quality, 11(3), 10, 1-37. DOI: 10.1145/3309699 


\title{
EXAMPLES OF LOCALIZATION OF CONSPIRACY THEORIES ON THE SOCIAL NETWORKING SITE FACEBOOK
}

\author{
Mārtiņš Pričins \\ $\bigotimes$ martins.pricins@lu.lv \\ ORCID: https://orcid.org/0000-0003-1307-4810
}

In times of uncertainty and anxiety, there is a growing need in society for quality and reliable information. The coronavirus infection and the associated impact on the daily lives of the population became a major challenge in various aspects, especially in the information environment on social media, where various types of misleading and unverified information began to spread rapidly. Academic literature distinguishes between misinformation, created and disseminated without manipulative or malicious intent, and disinformation, which are deliberate (often organized) attempts to manipulate information for economic or political reasons or to simply disrupting public communication processes (UNESCO 2018). According to the summary on the classification of false information, only a few authors in this field distinguish conspiracy theories as an important concept and a separate phenomenon in the information field (Kapantai et al. 2020). Conspiracy theories can be defined as non-factual stories because they have no established basis for truth. In them, important events are usually explained by a secret conspiracy by the government or influential individuals (Zannettou et al. 2018). Conspiracy theories have four characteristics: there is a group operating in secret to influence institutions, which usurps power, hides the truth, and benefits at the expense of the common good. Thus, a formula can be determined according to which the main elements of conspiracy theory are formed: participants involved + specific circumstances + motivation + victims (Uscinski, Parent 2014). Conspiracy theories are difficult to verify by default for a number of reasons. First, they often lack any evidence base, second, they are disseminated by individuals who themselves believe in their truth, and third, evidence that refutes the conspiracy is considered as further evidence of the conspiracy (EAVI 2018). The topic is worth researching because there are conditions in Latvia that may be conducive for the public's belief in conspiracy theories. One of these conditions is the low level of trust in the main state institutions: trust in the national parliament (19\%), in the government $(23 \%)$, in political parties (7\%), in public administration (27\%) and officials (27\%) (Eirobarometrs 2021; SKDS 2021). Also increasing mistrust in the mainstream media outlets of Latvia has been observed - from 36\% in 2020 to $48 \%$ in 2021 - which is a typical trend in the Baltic and Eastern European countries (Hajdu et al. 2021). The survey conducted by the Providus think tank in 2021 shows that there is a connection between one's trust in other people and their trust in the institutions of Latvia, where individuals who are less likely to trust others are also unlikely to trust institutions. Moreover, compared to other groups, people with basic education have a particularly low level of trust (around 22\%). The aim of this report is to 
find out what are the practical manifestations of conspiracy theories on the social networking site Facebook. Focusing on content in the Latvian language, with the help of the analysis tool CrowdTangle, the most popular posts of the news portals Delfi.lv and LSM.lv on Facebook were identified (which concern the topic of Covid-19 in January 2021), further analysis was done on the most popular comments (those that received the largest number of reactions). Three main groups of comments related to this topic have been identified, in which the features of conspiracy theories have been observed: coronavirus testing, power, and wealth. In the coronavirus test group, the comments stated that the tests were not trusted, that the numbers of infected people were "inflated" and that it was impossible to screen so many people during the day. The commentary group on power contains references to external forces that supposedly control the situation in the world, or in the country, and will not relinquish this power anytime soon. Wealth-related comments point to the need to "keep nations in poverty in order to facilitate manipulation." The results of the analysis show that the authors of conspiracy-theoryrelated posts on Facebook rarely post their own examples of localization on their personal Facebook pages, this is mostly done with users commenting on media entries on the social networking platform. In these comments, local news published by the media is interpreted in the context of the conspiracy theories prevalent at the time. Conspiracy theories expressed in these records are contradicting in the interpretations and facts presented in the articles. Moreover, they often display a lack of knowledge on the subject. In some cases, conspiracy theories are founded on the inconsistency of decisions and rapid changes in policy of Latvian officials, which become the basis for their localization.

Keywords: conspiracy theories, false information, social media, political communication

\section{References}

EAVI (2018). Infographic: Beyond Fake News - 10 Types of Misleading News - Seventeen Languages. www.eavi.eu. Retrieved from: https://eavi.eu/beyond-fake-news-10-typesmisleading-info/

Eirobarometrs (2021). Standarta Eirobarometrs 94. Sabiedriskā doma Eiropas Savienībā. Nacionālais zinojums. Riga: Kantar. Retrieved from: https://lvportals.lv/wwwraksti/TEMAS/FAILI/ EIROBAROMETRS_SAB_DOMA_ZIEMA_2020_2021_NACIONALAIS_ZINOJUMS_ LATVIJA.PDF

Hajdu, D., Klingová, K., Milo, D., Sawiris, M. (2021). GLOBSEC Trends 2021. Bratislava: GLOBSEC. Retrieved from: https://www.globsec.org/wp-content/uploads/2021/06/GLOBSEC-Trends2021_final.pdf

Kapantai, E., Christopoulou, A., Berberidis, C., Peristeras, V. (2020). A Systematic Literature Review on Disinformation: Toward a Unified Taxonomical Framework. New Media \& Society, 23(5), 1301-1326. DOI: 10.1177/1461444820959296

SKDS (2021). Latvijas barometrs. Latvijas iedzīvotāju noskaņojuma vērtējums. Retrieved from: https://www.skds.lv/docs/1414/Latvijas_barometrs_022021.pdf

UNESCO (2018). Journalism, 'Fake News' \& Disinformation. Paris: UNESCO Series on Journalism Education. Retrieved from: https://en.unesco.org/fightfakenews 
Uscinski, J. E., Parent, J. M. (2014). Conspiracy Theories in America. Oxford: Oxford University Press.

Zannettou, S., Sirivianos, M., Blackburt, J., Kourtellis, N. (2019). The Web of False Information: Rumors, Fake News, Hoaxes, Clickbait, and Various Other Shenanigans. Journal of Data and Information Quality, 11(3), 10, 1-37. DOI: 10.1145/3309699 


\title{
DZIMUMU LĪDZTIESĪBA 2020. GADĀ COVID-19 PANDËMIJAS IETEKME
}

\author{
Marita Zitmane \\ $\bigotimes$ maritaz@edu.lu.lv \\ ORCID: https://orcid.org/0000-0002-1672-9520
}

Covid-19 pandēmija apgrieza ikdienas dzīvi kājām gaisā. Mājsēde un sociālā distancēšanās nozīmēja, ka lielai daḷai sabiedrības, kas pārgāja uz attālināto darbu un mācībām mājās, būtiski samazinājās laika un telpas robeža starp algotu darbu, mājas darbu un aprūpes darbu, visam koncentrējoties vienā un tajā pašā telpā un bieži vien arī laikā (Craig 2020, 684). Covid-19 pandēmija ir atklājusi ilgstošu dzimumu nevienlīdzību darba tirgū, ìpaši sieviešu koncentrāciju elastīgākos, darba formu un laika ziṇā, un līdz ar to nestabilos un pārsvarā mazāk apmaksātos darbos. Pandēmija pastiprināja neapmaksāta mājsaimniecības darba slogu (dažos gadījumos arī vardarbību), ko sievietes piedzìvo mājās (Cooper, Mosseri 2020, 464). Kopš pandēmijas vairāki pētījumi ir parādỉjuši, ka sieviešu karjera, pat ja viṇas ir spējušas palikt darba vidē, ir ietekmēta negatīvi. Amerikas Savienotajās Valstīs apkopotā statistika liecina, ka tieši mātes biežāk nekā tēvi aiziet no darba kā aprūpētājas, saskaroties ar mājas darbu pieaugumu skolu un bērnu aprūpes iestāžu slēgšanas dēl. Starp precētiem pāriem, no kuriem abi vecāki strādāja attālināti, tieši mātes būtiski samazināja savu darba laiku, savukārt tēvu vidū darba laika apjoms, strādājot attālināti, nemainījās (Landivar et al. 2020, 1). Abi šie aspekti liecina, ka Covid-19 krīze pasliktina esošo dzimumu nevienlīdzību, kas ilgtermiṇā ietekmēs sieviešu nodarbinātību un labklājību. Raugoties uz situāciju Latvijā, pētījumu dati liecina, ka 31,8\% sieviešu radās papildu pienākumi mājsaimniecībā Covid-19 ārkārtējās situācijas laikā, par 12,4\% pārsniedzot rādītāju vīriešu grupā (Vanadziņš et al. 2020, 43). Būtisks pētījuma secinājums, kas raksturo dzimuma līdztiesības situāciju mājsaimniecības un bērnu aprūpē Latvijā, - atšķirības pa dzimumiem starp pienākuma sadali pirms Covid-19 un Covid-19 ārkārtējās situācijas laikā netiek novērotas. Gan pirms, gan Covid-19 ārkārtējās situācijas laikā ar bērnu ikdienas aprūpi nodarbojas galvenokārt sievietes - sieviešu īpatsvars attiecīgi ir 25,1\% un 27,2\%, vīriešu - 1,9\% un 2,8\%. Tātad sieviešu īpatsvars, kas ikdienā rūpējas par bērniem, vairāk nekā 10 (!) reizes pārsniedz vīriešu īpatsvaru neatkarīgi no analizējamā perioda (Vanadziņš et al. 2020, 56). Pētījumi norāda uz ilgtermiṇa sekām: pandēmija pastiprina sieviešu un vīriešu nevienlīdzību profesionālo sasniegumu/karjeras izaugsmē, tādējādi arī uz ienākumiem un pensijas uzkrājumiem, kā arī uz ekonomisko neatkarību. Covid-19 pandēmija pievērsa uzmanību dzimumu attiecībām un nodarbinātības, mājas darba un aprūpes sadalījumam. Daudzām sievietēm jau esošā darba un ǵimenes savienošanas kārtība bija maksimāli saspringta un tāpēc vērtējama kā neilgtspèjīga, pandēmija šo situāciju padarīja vēl sarežğītāku (Craig 2020, 690). Pandēmija arī piedāvā iespēju izvērtēt darba un gimenes savienošanu dzimumu līdztiesības ziṇā, lai izstrādātu politiku sieviešu, īpaši māšu, nodarbinātības atbalstam. 
Atslēgvārdi: Covid-19 pandēmija, dzimumu līdztiesība, darba un g̣imenes dzives savienošana, attālinātais darbs, nodarbinātība

\section{Atsauces}

Craig, L. (2020). Coronavirus, Domestic Labour and Care: Gendered Roles Locked Down. Journal of Sociology, 56(4), 684-692. DOI: 10.1177/1440783320942413

Landivar, C., Ruppanner, L., Scarborough, W., Collins, C. (2020). Early Signs Indicate That COVID-19 Is Exacerbating Gender Inequality in the Labor Force. Socius: Sociological Research for a Dynamic World, 6, 1-3. DOI: 10.1177/2378023120947997

Vanadziņš, I., Linde, A., Matisāne, L., Paegle, L., Rozentāle, S., Grīntāle, I., Arbidāne, I., Litavniece, L., Lonska, J., Mietule, I. (2020). Ziņojums par dažādu sociāli demogrāfisko grupu darba un privātās dzīves saskaņošanas iespējām Covid-19 izplatības mazināšanai noteikto ierobežojumu periodā. Rīga: Rìgas Stradiṇa universitāte, Vidzemes Augstskola, Rēzeknes Tehnologiiju akadēmija. 


\title{
THE IMPACT OF THE COVID-19 PANDEMIC ON GENDER EQUALITY IN 2020
}

\author{
Marita Zitmane \\ $\bigotimes$ maritaz@edu.lu.lv \\ ORCID: https://orcid.org/0000-0002-1672-9520
}

The Covid-19 pandemic has turned daily life upside down. Home schooling and social distancing has meant that, for a significant proportion of society who switched to teleworking and studying at home, the boundaries of time and space, of paid work, homework and care work, were significantly reduced; they became concentrated in a single space and, often, at the same time (Craig 2020,684). The Covid-19 pandemic has revealed persistent gender inequalities in the labour market, in particular the concentration of women in more flexible forms of work and work time and thus in precarious and mostly low-paid jobs. The pandemic exacerbated the burden of unpaid domestic work (and in some cases violence) experienced by women at home (Cooper, Mosseri 2020, 464). Since the pandemic, several studies have shown that women's careers, even if they have been able to stay in the workplace, have been adversely affected. Statistics compiled in the United States of America show that mothers are more likely than fathers to leave their jobs in the face of an increase in domestic work (due to the closures of schools and childcare facilities). Among married couples, where both parents worked remotely, it was the mothers who significantly reduced their working hours, while the amount of working time among fathers did not change (Landivar et al. 2020,1). Both aspects show that the Covid-19 crisis is exacerbating existing gender inequalities, which will have a long-term impact on female employment and well-being. Regarding the situation in Latvia, research data indicates that $31.8 \%$ of women had additional responsibilities in the household during the Covid-19 emergency, which is $12.4 \%$ higher than in the male group (Vanadziņš et al. 2020, 43). An important finding of the study, which characterizes the situation of gender equality in the household and childcare in Latvia, was those substantial differences in the division of responsibilities among genders before and during the Covid-19 outbreak were not observed. Both before and during the Covid-19 emergency $25.1 \%$ and, respectively, $27.2 \%$ of women $(1.9 \%$ and $2.8 \%$ of men) were responsible for childcare. Consequently, regardless of the period analyzed, it can be concluded that the proportion of women who provide daily primary care for their children is more than 10 times higher than the proportion of men (Vanadziņš et al. 2020, 56)! In conclusion, research points to long-term consequences for gender equality: the pandemic exacerbates inequalities in terms of professional achievement/career development and, therefore, impacts income and pension savings as well as economic independence. The Covid-19 pandemic has exasperated and shed light on gender relations, the distribution of employment, of domestic work and care. For many women, pre-existing work-family arrangements were already stressful to the point of unsustainability and the pandemic has brought with it significant potential to test and disrupt long-standing patterns 
(Craig 2020, 690). Nonetheless, the pandemic offers an opportunity to assess the reconciliation of work and family in a gender-sensitive way, to develop policies to support the employment of women, especially mothers.

Keywords: Covid-19 pandemic, gender equality, reconciling work and family life, teleworking, employment

\section{References}

Craig, L. (2020). Coronavirus, Domestic Labour and Care: Gendered Roles Locked Down. Journal of Sociology, 56(4), 684-692. DOI: 10.1177/1440783320942413

Landivar, C., Ruppanner, L., Scarborough, W., Collins, C. (2020). Early Signs Indicate That COVID-19 Is Exacerbating Gender Inequality in the Labor Force. Socius: Sociological Research for a Dynamic World, 6, 1-3. DOI: 10.1177/2378023120947997

Vanadziňš, I., Linde, A., Matisāne, L., Paegle, L., Rozentāle, S., Grīntāle, I., Arbidāne, I., Litavniece, L., Lonska, J., Mietule, I. (2020). Ziñojums par dažādu sociāli demogrāfisko grupu darba un privātās dzīves saskaņošanas iespējām Covid-19 izplatības mazināšanai noteikto ierobežojumu periodā. Rīga: Rìgas Stradiņa universitāte, Vidzemes Augstskola, Rēzeknes Tehnologiiju akadēmija. 